NBER WORKING PAPER SERIES

\title{
WHAT DETERMINES GIVING TO HURRICANE KATRINA VICTIMS? EXPERIMENTAL EVIDENCE ON INCOME, RACE, AND FAIRNESS
}

\author{
Christina M. Fong \\ Erzo F.P. Luttmer \\ Working Paper 13219 \\ http://www.nber.org/papers/w13219
NATIONAL BUREAU OF ECONOMIC RESEARCH
1050 Massachusetts Avenue
Cambridge, MA 02138 \\ July 2007
}

Funding by NSF (grant \# 0555004 and 0555049 ), TESS, and Knowledge Networks is gratefully acknowledged and we thank Robyn Dawes for his guidance as Co-PI on this project. Erzo Luttmer also gratefully acknowledges funding from the National Institute on Aging through Grant Number T32-AG00186 to the National Bureau of Economic Research. Andra Hibbert, Nathanial Peterson and Zoe Savitsky provided excellent research assistance and Jennifer Shultis kindly agreed to do the voice-over for the slide show. We are very grateful to over 40 colleagues for insightful comments on the design and interpretation of the results of the experiment. We also received useful comments from seminar participants at Chicago, Harvard, IZA, Kentucky, Michigan, NBER, Notre Dame, Ohio State, Princeton, Stanford, Tilburg, Tufts, and Virginia. All errors are our own. The views expressed herein are those of the author(s) and do not necessarily reflect the views of the National Bureau of Economic Research.

(C) 2007 by Christina M. Fong and Erzo F.P. Luttmer. All rights reserved. Short sections of text, not to exceed two paragraphs, may be quoted without explicit permission provided that full credit, including (C) notice, is given to the source. 
What Determines Giving to Hurricane Katrina Victims? Experimental Evidence on Income, Race, and Fairness

Christina M. Fong and Erzo F.P. Luttmer

NBER Working Paper No. 13219

July 2007

JEL No. C93,D63,D64,J71

\begin{abstract}
We investigate determinants of private and public generosity to Katrina victims using an artifactual field experiment. In this experiment, respondents from the general population viewed a short audiovisual presentation that manipulated respondents' perceptions of the income, race, and deservingness of Katrina victims in one of two small cities. Respondents then decided how to split $\$ 100$ between themselves and a charity helping Katrina victims in this small city. We also collected survey data on subjective support for government spending to help the Katrina victims in the cities. We find, first, that our income manipulation had a significant effect on giving; respondents gave more when they perceived the victims to be poorer. Second, the race and deservingness manipulations had virtually no effect on average giving. Third, the averages mask substantial racial bias among sub-groups of our sample. For instance, the subgroup of whites who identify with their ethnic or racial group strongly biased their giving against blacks. Finally, subjective support for government spending to help Katrina victims was significantly influenced by both our race and deservingness manipulations, but not by the income manipulation. White respondents supported significantly less public spending for black victims and significantly more for victims who were described in more flattering terms, such as being helpful and law-abiding.

Christina M. Fong

Department of Social \& Decision Sciences

Carnegie Mellon University

208 Porter Hall

Pittsburgh, PA 15213

fong2@andrew.cmu.edu

Erzo F.P. Luttmer

Kennedy School of Government, Mailbox 25

Harvard University

79 John F. Kennedy Street

Cambridge, MA 02138

and NBER

erzo_luttmer@harvard.edu
\end{abstract}




\section{Introduction}

On August 29, 2006, Hurricane Katrina made landfall in southwest Louisiana. It was the costliest hurricane in U.S. history, causing an estimated $\$ 81$ billion of damage (Nordhaus, 2006). Low-income and black communities were especially hard hit. Among the public, there were widespread opinions that relief efforts were inadequate and many alleged that Americans would have cared more about Katrina's victims if they had not come to a large extent from minority and economically disadvantaged groups. ${ }^{1}$ These opinions suggest generosity to low-income and black victims on the part of those who voiced support for more aid but a revealed preference on the part of many others for relatively little aid to these victims. In this study, we empirically investigate how the income, race, and other characteristics of Katrina victims affected generosity towards them.

To answer this question, we conducted an artifactual field experiment on charitable giving to Katrina victims. Over 1300 respondents, who were roughly representative of the adult U.S. population, viewed an audiovisual presentation about Katrina victims in a small city that was heavily affected by the hurricane (Slidell, LA or Biloxi, MS). Without using deception, we use the audio information to manipulate perceptions of the income and deservingness of the victims, and show pictures of mostly black or of mostly white victims to manipulate perceptions of race. As explained in more detail below, we implemented the picture manipulation such that it creates exogenous variation in the perceived race of the victims but controls for any effect of the backgrounds of the pictures. This design enables us to independently manipulate the perceived race, economic well-being, and deservingness of Katrina victims while still achieving a relatively high level of ecological validity. The fact that we use a large, broadly representative sample is important because of growing concerns and recent evidence that giving in experiments using smaller and less representative samples (e.g., college students) might misrepresent giving in the broader population. $^{2}$

We then collect two primary measures of generosity to the victims. First, we measure gifts of real money to the local chapter of Habitat for Humanity that benefits Katrina victims in the city described in the presentation. We give our respondents a $10 \%$ chance of receiving $\$ 100$.

\footnotetext{
${ }^{1}$ According to a Gallup Poll collected from September 8-11, 2005, 60\% of blacks and $12 \%$ of whites believed that the government's response was slow because many of the victims were black.

${ }^{2}$ For instance, Jeffrey Carpenter et al. (2007) found that giving in dictator games differed significantly between two different sub-populations - college students versus a broadly representative sample of Vermont residents.
} 
Prior to learning the outcome, respondents are asked to decide how much, if any, of this $\$ 100$ they would like to donate to the local chapter of Habitat for Humanity. Thus, though we do not phrase it this way to respondents, they effectively play a dictator game against the local Habitat for Humanity chapter. Offers in this dictator game provide a behavior-based measure of how much people care about some types of Katrina victims relative to others. An advantage of this approach is that it allows us to estimate how generosity measured with real monetary incentives responds to several tightly controlled and independently manipulated factors. A limitation is that, because this is not a natural field experiment, the usual limits to ecological validity apply. ${ }^{3}$ Second, we ask respondents about their subjective support for government spending on rebuilding and assistance to the Katrina victims in the small city. In addition to these generosity measures, we collect control variables, various attitudinal variables, and perceptions of characteristics of the victims, including their income, racial composition, and deservingness.

We find that the determinants of gifts of real money to Katrina victims differ from the determinants of subjective support for government spending to help Katrina victims. We have three main findings concerning private generosity, as measured by giving to Katrina victims in the dictator game. First, the income of the victims has a significant effect; respondents gave more when our presentation suggested that the victims were relatively poor. Second, perhaps surprisingly, neither the race nor the deservingness of recipients has a significant effect on giving on average. ${ }^{4}$ Third, the averages mask substantial heterogeneity in racial bias. In particular, whites who identify with their ethnic or racial group bias their giving against blacks while whites who do not do so bias their giving in favor of blacks. Also, blacks who identify more strongly with their ethnic or racial group bias their giving more in favor of blacks. Regarding support for public generosity, we find that both the race and deservingness manipulations have significant effects on subjective support for government assistance to Katrina victims while the income

\footnotetext{
${ }^{3}$ For example, respondents make a donation using windfall money, not their own earned income; they listen to the presentation because we tell them to, not because they choose to; they are asked to give under conditions with relatively low transactions costs and a low sense of entitlement to the money, as opposed to taking the initiative to send a check or make a call to give money which is already in their possession. See Levitt and List (2007) for an extensive discussion of the external validity of experimental findings.

${ }^{4}$ This finding is surprising in light of research showing race effects in a variety of settings. In addition to the works cited below, see, for instance, Munnell et al. (1996) and Cutler, Glaeser and Vigdor (1999) on housing market discrimination, and Altonji and Blank (1999), Bertrand and Mullainathan (2004), and Pager et al. (2006) on labor market discrimination. List (2004) finds statistical discrimination in field experiments on trading in sports card markets. In the political process, racial heterogeneity has been linked to riots (DiPasquale and Glaeser, 1998), lower participation in social activities (Alesina and La Ferrara, 2000) and lower levels of trust (Alesina and La Ferrara, 2002). Individuals also prefer to form racially homogenous political jurisdictions (Alesina et al., 2004).
} 
manipulation has no significant effect. White respondents on average support more public assistance when they see pictures of white victims and when they are manipulated to perceive the victims as relatively more deserving.

Thus, our findings show no effect of race and deservingness in own charitable giving to Katrina victims, despite the fact that the same race and deservingness manipulations had significant effects on support for public assistance to Katrina victims. ${ }^{5}$ One possible reason for this may be that respondents believe that Habitat for Humanity only provides assistance to deserving individuals, while government programs may not. If this is true, then there may not be enough variation in perceptions of deservingness of recipients in our charity experiment. This could also explain why race does not matter in our charity experiment, if racial bias is mediated by perceptions of relative deservingness of white and black recipients, as some have argued (Gilens, 1999).

Our experiment belongs to a burgeoning set of field experiments on charitable giving to various causes such as university fundraisers and public radio. ${ }^{6}$ However, there are at least two noteworthy differences. First, our experiment samples the general adult U.S. population while many of the existing field experiments sample sub-populations. Second, although we did our best to maximize external validity, we measure behavior with a fairly traditional dictator game as opposed to measuring a natural decision made by subjects who are unaware that they are under study and are typically acting with their own money.

Our findings of racial bias and fairness concerns in public generosity are consistent with the literature on redistributive politics, which has shown that both race and fairness have substantial effects on redistributive preferences and outcomes. Regarding race, there is evidence that the racial and ethnic composition of cities and states affects actual expenditures on public redistribution (Alesina et al., 1999, Alesina et al., 2001) and attitudinal support for redistribution (Luttmer, 2001), and that racial attitudes matter for redistributive demands and political ideology

\footnotetext{
${ }^{5}$ Our findings are consistent with Levitt (2004), Antonovics et al. (2005), and List (2006), who find little evidence of racial discrimination in behavior on game shows. Of course, the absence of racial bias in publicly observable behavior does not rule out the possibility of racial biases in more anonymous behavior (such as charitable giving).

${ }^{6}$ Some of the findings from prior field experiments on charity are that donors are sensitive to price (Eckel and Grossman, 2005, 2006, Karlan and List, forthcoming), to expectations about the giving of other donors (Frey and Meier, 2004, Croson and Shang, 2005), to the mechanism used to elicit giving (Landry et al., 2005), to gifts from the solicitor (Falk, forthcoming), and to the auction mechanism used to elicit donations (Carpenter et al., Forthcoming).
} 
(Gilens, 1999, Lee and Roemer, 2006). ${ }^{7}$ Racial biases have also been documented in attitudinal support for public aid to Katrina victims (Iyengar and Morin, 2006). ${ }^{8}$ Regarding fairness, there is abundant evidence that people are more generous when they perceive recipients as deserving. ${ }^{9}$

Finally, our results contribute to the literature on the roles of race and deservingness in laboratory experiments. Racial and ethnic biases have been found in several trust games, but not in dictator games (Fershtman and Gneezy, 2001, Eckel and Wilson, 2003, Bouckaert and Dhaene, 2004, Burns, 2004, 2006, Haile et al., 2006). ${ }^{10}$ Other studies show that subjects give substantially more to recipients of laboratory dictator games when the recipients are perceived as deserving. For example, subjects give three times more to the American Red Cross than to anonymous recipients (Eckel and Grossman, 1996), and they give more to welfare recipients when they perceive that the recipients are poor because of bad luck rather than laziness (Fong, Forthcoming). Again, the fact that we do not find effects of race or deservingness of recipients in our dictator game might potentially be due to a lack of variation in perceptions of the deservingness of the recipients. After all, the recipients are all Katrina victims selected to get assistance by Habitat for Humanity.

\section{Description of the Experiment}

\subsection{Knowledge Networks and its Respondent Pool}

We contracted with Knowledge Networks, a commercial survey and marketing research firm founded by two Stanford political science professors, to administer our survey instrument to a sample of their respondents. Knowledge Networks maintains a panel of respondents that it

\footnotetext{
${ }^{7}$ Pager and Freese (2006) find experimental evidence that respondents report a higher level of support for government job training and placement assistance for unemployed blacks than for unemployed whites. It is not clear whether this is driven by more charitable feelings toward black unemployed individuals or by a belief that blacks are less likely to find employment absent government training and placement assistance.

${ }^{8}$ See also Harris-Lacewell et al. (2007). They examine the effect of photographs of Katrina victims that were featured prominently in the news media on attitudes to Katrina victims. The photographs simultaneously vary economic well-being, race and family structure and elicit responses consistent with group loyalty.

${ }^{9}$ It is beyond the scope of this paper to review the literatures on altruism and fairness. For reviews see Camerer (2003), Fehr and Schmidt (2003), Konow (2003), Sobel (2005) and various chapters in the Handbook on the Economics of Giving, Reciprocity and Altruism (Kolm and Ythier, 2006). For reviews of the roles of altruism and fairness in redistributive politics, see Alesina, Glaeser and Sacerdote (2001) and Fong, Bowles and Gintis (2006).

${ }^{10}$ See also Glaeser et al. (2000).
} 
recruits through random-digit-dialing. These respondents agree to take a 15-20 minute survey once a week via the Internet using a PC or WebTV in exchange for free Internet and WebTV access. In addition, the panelists often receive incentive payments and rewards through a loyalty program. Knowledge Networks collects basic demographic characteristics for all its panelists, and its panelists are roughly representative of the adult U.S. population in terms of these characteristics. In addition to demographic characteristics, Knowledge Networks already collects certain additional characteristics (such as political attitudes and media exposure), which means that we did not need to collect this information as part of our survey instrument. Appendix Table A.1 compares the means of the demographic variables collected by Knowledge Networks to the means for the same variables in the Current Population Survey. Although the differences between the Knowledge Networks means and the CPS means are sometimes statistically significant, the means of the demographic variables in the two datasets are comparable in magnitude. Our main survey instrument, attached in full in Appendix A, consists of four parts which we now describe in turn in Sections 2.2 and 2.3.

\subsection{Randomized Manipulations of Income, Race, and Deservingness}

Part I of the survey experimentally manipulates the perceived income, race, and deservingness of Katrina victims, without using deception, using a brief audiovisual presentation about a small city (Slidell, LA or Biloxi, MS) that was hit by Katrina. Our presentation consists of a slide show of eight photos of actual people in each city after the hurricane with an accompanying audio story about the city's residents and Habitat for Humanity. Many photos showed devastation caused by Katrina, such as extensive flooding or demolished housing. Others showed residents receiving in-kind aid.

We manipulate race by using photos of mostly white residents in one treatment condition and photos of mostly black residents in the other. ${ }^{11}$ We match the gender, age and number of people shown, as well as the background and the emotional connotation of the photos as closely as possible. We "blur" the people in the photos so that their race shows through but their

\footnotetext{
${ }^{11}$ We did not use pictures of exclusively one race in order to reduce the chance that respondents would infer that our study is partly about race. Of the eight pictures, six pictures show Katrina victims of the race corresponding to the manipulation, but the third picture shows a Katrina victim of the other race and the sixth picture shows both black and white Katrina victims. Thus, roughly $80 \%$ of the people shown in the pictures were of the race corresponding to the manipulation.
} 
attractiveness and other features are obscured. ${ }^{12}$ We used photos to manipulate race because we were concerned that other methods of manipulating race, such as mentioning the racial composition of the cities in the audio description, would alert respondents to the fact that the study is in part about race. Discriminating on the basis of race violates social norms while discriminating on the basis of recipient income and deservingness is less socially unacceptable. Thus, it was especially important not to signal to respondents that our study was in part about race because doing so might cause them to change their behavior to comply with social norms against racial discrimination.

One way to look for racial bias in giving is simply to test the treatment effect of the victims' race shown in these blurred photos. However, because we use real photographs, the backgrounds shown in the photos also vary with the race of the victims. To control for backgrounds of the photos, we create a control condition that obscures the race of the people in the photos by filling in their images with blue coloring so they appear as solid blue shapes.

Together, these two manipulations - the race of the people in the picture and whether the people are "blurred" or "blued" - yield four different types of pictures. Each respondent is randomized into one of the resulting four cells:

A. ("black pictures \& blurred") Pictures with mostly black victims, race shown but face is anonymized

B. ("white pictures \& blurred") Pictures with mostly white victims, race shown but face is anonymized

C. ("black pictures \& blued") Pictures with mostly black victims, race concealed by solid blue shape

D. ("white pictures \& blued") Pictures with mostly white victims, race concealed by solid blue shape.

An example of these types of pictures is shown in Figure 1. These four types of pictures allow us to use a difference-in-differences (DD) design to estimate the effect of the race of the people shown in the pictures on outcome variables, such as the amount given to Habitat for Humanity. We calculate average giving in each cell and estimate racial bias as the difference in giving in response to pictures of black and white victims when the race can be seen (A-B) minus this difference when the race cannot be determined (C-D). This yields: (A-B)-(C-D). Alternatively,

\footnotetext{
${ }^{12} \mathrm{We}$ do this by reducing the resolution of the people in the picture (by pixilating the images of people).
} 
we perform conceptually the same estimation in a regression framework, allowing us to control for the other experimental manipulations and for respondent characteristics (such as income, regions, etc). Since experimental conditions are randomly assigned, these controls do not substantially affect the estimated effect of recipient race, but they make the estimate somewhat more precise.

We varied the audio information going with the pictures along nine characteristics that we judged to be (i) likely determinants of generosity and (ii) plausibly correlated in the public's mind with the racial composition of the city. These audio manipulations are: 1 . The economic situation of the city, 2. Political preferences in the city, 3. Whether many residents attend church, 4. Whether many residents are law-abiding, 5. Whether residents help each other, 6 . Whether many residents received government cash benefits before Katrina hit (rather than working), 7. Whether recipients had to contribute labor to their home from Habitat ("sweat equity"), and 8. Whether residents took reasonable precautions against hurricanes. In addition, we varied the audio along a ninth dimension: Whether looting was mentioned in the audio text or not. We did this to see whether mentioning a charged topic such as looting would bring out racial biases in giving (it did not).

We took care never to provide incorrect information. Instead, by selectively providing or omitting certain information, we tried to influence respondents' perceptions of the city and of Katrina victims who receive housing from Habitat for Humanity in that city. Appendix Table A.2 spells out the exact variations in the audio text that correspond to these nine manipulations as well as the corresponding perception questions. In total, our audiovisual presentation contains twelve randomly assigned experimental manipulations: two picture manipulations (race and whether the pictures were blurred or blued), nine audio manipulations, and which city was shown. Details on the randomization procedure are provided in Appendix B.

\subsection{Outcome and Control Variables}

Part II of the survey measures actual and hypothetical giving to Katrina victims. For our actual measure, we ask the respondents how they would like to split $\$ 100$ between themselves and the charity, Habitat for Humanity, in the city about which they saw the presentation. Because we want to ensure that the answer can be interpreted as a revealed preference measure, we 
implement the decision for $10 \%$ of the respondents. To credibly convey that each respondent has a $10 \%$ chance of getting his or her decision implemented, we assign each respondent a random number between 0 and 9 , and tell respondents that their decision will be implemented if their number is equal to the first digit of the Pick3 game of the Louisiana State Lottery on a specified future date. To further emphasize that their decision can have real consequences, we also tell them that if their number equals the lottery number, Habitat will send them a note acknowledging how much they gave. ${ }^{13}$ See Appendix A for the exact wording.

For our measure of hypothetical giving, immediately after having made their decision on how much to give to Habitat, we ask "Suppose that you had not just given [the amount they just gave] to Habitat for Humanity. Instead, suppose that Habitat for Humanity in [city] had mailed a letter to your home describing the effects of Katrina on [city] and had asked you for a donation. How much, if anything, would you have given?"

Part III asks respondents about their perceptions of a number of characteristics of Katrina victims who receive housing from Habitat in that city. The purpose of this is to check that our manipulations changed the corresponding perceptions of the Katrina victims. As we show in Appendix C, almost all of our audio manipulations have significant effects on the corresponding perceptions. In order not to bias responses to attitudinal questions, we do not mention race in the survey until the end of the fourth section. There, we ask about respondents' perceptions of the racial composition of Habitat for Humanity recipients in the relevant city and the racial composition of all residents in that city. As we show in Appendix C, our race manipulation has a significant effect on these perceptions in the expected direction.

Part IV collects two subjective measures of generosity to Katrina victims as well as control variables. To obtain the subjective measures of generosity, we ask respondents, on a 7-point scale, whether they think charities should spend more or less on Katrina victims in the city in question, and whether they think the government should spend more or less on Katrina victims in the city in question. Control variables include, among other things, prior charitable giving, racial attitudes, and questions about the respondent's life priorities.

\footnotetext{
${ }^{13}$ Knowledge Networks has an ongoing relationship with its panelists. The respondents therefore likely understand that Knowledge Networks does not give them surveys in which promises are made that are subsequently not carried out, because this would damage this relationship. We are therefore reasonably confident that the respondents believed our instructions and acted accordingly.
} 
While most respondents took the main survey instrument, we had a fraction of respondents take an alternative version of the instrument: a "race-salient" instrument that states at the outset that the study is about race, or a "full-stakes" instrument in which all respondents play the $\$ 100$ dictator game with certainty instead of having just a $10 \%$ chance of playing the game. The racesalient and full-stakes instruments only consisted of the blurred pictures condition. Each respondent participated in only one of the three versions of our instrument.

\section{Average Effects of Treatments and Respondent Characteristics on Giving}

We fielded the three surveys from June 6-19, 2006 and received 1530 completed surveys. ${ }^{14}$ Of these, 182 respondents reported that they could not hear the audio component of the slide show. We did not administer the giving and perceptions parts of the survey to these respondents, and we do not use their data in this paper. An additional 5 respondents failed to report a decision on how much to give in the experiment, so we dropped these observations. This leaves 1343 surveys that contain all four parts. The main instrument was completed by 1,101 respondents, of which 247 are African American. The median completion time was 22 minutes. These respondents are roughly nationally representative except for an intentional over-sampling of black respondents. We weight our results to correct for this over-sampling. The race-salient and full-stakes instruments were only administered to non-black respondents and are thus roughly representative of the non-black population. The race-salient instrument was completed by 118 respondents and the full-stakes instrument by 124 respondents. Summary statistics of the variables in the resulting dataset are provided in Appendix Table A.3.

On average, respondents gave $\$ 65$ to Habitat, with $44 \%$ of respondents giving the full hundred dollars, $20 \%$ giving half and $9 \%$ giving nothing. This level of giving is quite generous compared to average offers in laboratory dictator games, which are often around $20 \%$ of the pie (Camerer, 2003). This is consistent with prior findings that show substantially larger offers to charities than to anonymous subjects. For example, Catherine Eckel and Philip Grossman (1996)

\footnotetext{
${ }^{14}$ Knowledge Networks invited at total of 2608 panelists to take the survey. The response rate was $65 \%$, with 1700 respondents opening the survey. The completion rate was $90 \%$, yielding 1530 completed surveys. Completion of the survey does not appear to depend on our experimental manipulations. The hypothesis that our experimental manipulations had no effect on completion of the survey cannot be rejected ( $\mathrm{p}$-value $=0.27$ ).
} 
found that offers in dictator games were three times higher to the American Red Cross than to anonymous recipients. Furthermore, Viscusi and Zeckhauser (2006) present attitudinal data that show a great deal of support for governmental aid to disaster victims. Finally, since people tend to give more to specifically identified Habitat for Humanity recipients (Small and Loewenstein, 2003) than to unidentified Habitat recipients as was the case in our design, giving might have been even higher if we had asked our respondents to give to identified Habitat for Humanity recipients.

\subsection{Treatment Effect of the Race Manipulation}

In Table 1, we present the effect of the picture manipulations on the dollar amount given by respondents to Habitat using unweighted data from the main instrument. In the first column, the people in the pictures are blurred, allowing their race to show. Average giving in this treatment condition was $\$ 65.5$. The second column shows the "blue" condition in which all individuals shown in the pictures were rendered blue. In this condition, the type of picture should not affect respondents' estimates of the racial composition of Habitat recipients, unless the background of the picture contains cues about race. Average giving in the blue condition was $\$ 64.8$. Thus, offers in the two conditions are very similar, which lends support for using the blue condition as a control group.

Column 1 of Table 1 shows that respondents who see pictures with black victims in the blurred treatment condition gave, on average, $\$ 66.3$ to the local Habitat for Humanity chapter, while those seeing pictures with white victims gave on average \$64.7. Thus, when race was revealed in the blurred pictures, respondents gave about $\$ 1.6$ more in response to black pictures, but this difference is not statistically significant. Column 2 shows that in the "blue" condition, respondents gave on average $\$ 65.6$ when black pictures were shown and $\$ 63.9$ when white pictures were shown. Thus, they gave $\$ 1.7$ more in response to black pictures when race was concealed ("blue"), but again this difference is not statistically significant. The resulting DD estimate for the overall sample is $-\$ 0.1$ and is not statistically significant. Thus, the DD implies that after subtracting out the effect of the backgrounds in the pictures, seeing black pictures has a small and statistically insignificant effect on giving. 
Table 2 presents regressions of giving on the picture manipulations, audio manipulations, dummies for the version of the survey instrument, and demographic controls. We now weight observations to correct for the oversampling of black respondents. In order to maximize precision, we now also include observations from the race-salient and full-stakes instruments. As we show in Section 4.2, the race effect in these instruments is not statistically different from that in the main instrument, so we feel comfortable pooling the instruments. The coefficient on Black pictures $\times$ Blurred in the regression results corresponds to the DD estimate in Table 1. As before, respondents do not significantly change the amount they give in response to seeing black pictures in which race is visible. In the overall sample (shown in column 1), the response is $\$ 2$.2. Thus, the point estimate suggests that there is little effect of victims' race on giving, but given that the $95 \%$ confidence interval on this estimate ranges from about $-\$ 10$ to $\$ 5$, we cannot rule out a moderately large racial bias in giving in the overall sample. ${ }^{15}$

Columns 2 and 3 present the estimates for non-Hispanic white respondents and non-Hispanic black respondents, respectively. ${ }^{16}$ In both of these sub-samples, the coefficient on Black pictures $x$ Blurred is statistically insignificant. Among whites the estimated response is $-\$ 4.1$ with a $95 \%$ confidence interval of roughly $-\$ 13$ to $\$ 5$. Among blacks, the estimated response is $\$ 5.6$ with a $95 \%$ confidence interval of roughly $-\$ 11$ to $\$ 22$. Thus, in these sub-samples, the point estimates suggest small racial biases in favor of the respondent's own racial group. Although these estimates are statistically insignificant, the relatively wide confidence intervals mean that in these smaller samples, we cannot rule out substantial racial biases - especially in favor of one's own racial group. ${ }^{17}$

The coefficient on Blurred shows by how much giving changes when respondents see the blurred rather than the blued version of the white pictures. In the overall sample and the subsample of whites, these effects are roughly $\$ 5$. In the sub-sample of blacks, this effect is negative but close to zero and statistically insignificant. The coefficient on Black pictures shows the effect of seeing blued black versus blued white pictures. In the overall sample and white subsample, these effects are small and insignificant, meaning that backgrounds of the pictures with

\footnotetext{
${ }^{15}$ Blacks are poorer and, as we show in Section 3.2 below, giving to poorer people is higher. Accounting for the fact that giving in response to black victims should have been higher because they are poorer, we find a racial bias of $-\$ 2.8$ with a standard error of $\$ 4.0$.

${ }^{16}$ From now on we will refer to non-Hispanic white respondents and non-Hispanic black respondents simply as white and black respondents, respectively.

${ }^{17}$ We investigate the possibility of racial group loyalty in more detail below and find no significant evidence of it.
} 
black victims did not induce a different amount of giving than the backgrounds of the pictures with white victims. In the black sub-sample, this effect is somewhat larger (-\$7.3) but statistically insignificant.

A natural question is how to interpret the magnitude of the effects of our race manipulation. In principle, one might try to scale the effect of this manipulation on giving by its effect on perceptions of the racial composition of Katrina victims. The difficulty in doing this is that one must either collect the measure of generosity first or the measure of race perceptions first, and whichever measure is collected second is contaminated by responses to the first measure. For example, whites who bias their giving against blacks may bias downward their reported estimate of the fraction of victims who are black to avoid appearing racist - either to themselves or the investigators. Indeed, the results suggest that this is the case. As we explain below, whites who identify with their ethnic or racial group bias their giving significantly against blacks (see Section 4.4) but do not report perceiving a higher fraction of victims who are black when they are in the black treatment condition (see Appendix C). In contrast, whites who do not identify with their ethnic or racial group bias their giving in favor of blacks and do report perceiving a substantially higher fraction of victims who are black when they are in the black treatment condition (significant at the one-percent level). ${ }^{18}$

\subsection{Treatment Effects of the Income and Deservingness Manipulations}

The effects of the audio manipulations on giving are given by the coefficients on the dummy variables for these manipulations. We find a significant effect of the manipulation of the economic situation of the city. In both the overall sample and the sample of white respondents, respondents gave significantly less when we told them that the city was relatively economically advantaged. This effect is $-\$ 4.2$ in the overall sample and $-\$ 6.1$ in the sample of white respondents. In the black sample, however, the effect of recipient income is insignificant and slightly positive. It should be kept in mind that the income manipulation may have affected

\footnotetext{
${ }^{18}$ If one trusted the measures of perceptions of racial composition, then, according to unreported regressions on the sample of white respondents, a 10 percentage point increase in the perceived percentage blacks minus the perceived percentage white reduces giving by $\$ 1.4$ with a standard error of $\$ 2.3$. The standard deviation of the perceived percentage blacks minus the perceived percentage whites is 38 . Thus, a one standard deviation increase in perceived fraction black minus white reduces giving by approx $\$ 5.5$ among white respondents.
} 
giving not only through its effect on perceived recipient income but also through the perceived economic situation of the city as a whole.

It is striking that the manipulations intended to affect perceptions of deservingness, such as whether victims helped others in need (in the white sample) or whether victims took reasonable precautions against hurricanes, do not have statistically significant effects on giving, despite the standard error on them being just \$1.9 in the overall sample and \$2.3 in the sample of whites. The one exception to this is that, in the black sample, being told that the Katrina victims were willing to help others in need increases giving significantly by $\$ 10$.

As we show in Appendix $\mathrm{C}$, the generally weak effects of these manipulations on giving are not due to manipulation failures. Almost all of the deservingness manipulations have statistically significant effects on the perceptions that they were designed to affect. Furthermore, as we discuss in more detail in Section 5.1, while these manipulations do not affect private forms of generosity to the Katrina victims, they do have highly significant effects on support for public spending to help Katrina victims.

\subsection{Effects of Characteristics of Respondents}

Because the demographic characteristics of respondents are not experimentally manipulated, the effects of respondent characteristics on giving should be interpreted as partial correlations rather than causal effects. We find two main results. First, giving roughly increases in socioeconomic status. In the overall sample, blacks give significantly less than whites and giving increases in real household income. Among blacks, those with at least some college education give significantly more than those with high school degrees only.

Second, a history of charitable giving strongly predicts giving in the experiment setting, which confirms findings by Benz and Meier (2006). This is important because this strong association of giving in our experiment with prior real-life charitable behavior increases our confidence in the external validity of our key outcome variable. The variable Log giving to charity in 2005 is the demeaned value of the log of the total amount given to charity in 2005 for those who gave positive amounts, and zero for those who gave nothing. The variable named Any charity giving in 2005 is a dummy for having made any charitable contribution in 2005. Because Log giving to charity in 2005 is demeaned, the coefficient on this variable shows that the average 
charitable donor gave $\$ 11$ more in our experiment than the average non-donor. In addition, we find that those who made higher contributions to charity in the past also gave significantly more in our experiment. The measures of past charitable giving to Katrina relief are defined analogously. Controlling for total prior charitable giving, past charitable giving to Katrina relief has a weakly positive effect on giving in our experiment. This implies that those who have given to Katrina relief in the past are more generous to Katrina victims overall, because they do not give less in our experiment to compensate for higher levels of past giving to Katrina relief.

\subsection{Robustness Checks}

The insignificant effect of the race manipulation and the significant effect of recipient income are both robust. Table 3 presents some of these robustness checks. The first row repeats the baseline regression for the overall sample, the sample of white respondents, and the sample of black respondents, presenting the race and income effects from rows 1 and 5 of Table 2 .

Each subsequent row is like the first row in all respects except that either one aspect of the specification or one aspect of the sample is changed. The second row is like the first, but uses only the main sample, which excludes the observations from the race-salient and the full-stakes survey instruments. The results in this row do not differ much from the results in the baseline.

The third row is like the first, except that it only uses the part of the overall sample that was shown photos of Slidell. The results in this row are qualitatively similar to the results of row 1. However, the effects of the income manipulation are larger in magnitude, and still in the expected direction, in all three sub-samples. Also, in the overall sample and the white sample, the effect of the race manipulation is even smaller in magnitude than in Row 1. The fourth row is like the first, except that it only uses the sample from Biloxi. Compared to row 1, the effects of the race manipulation are larger in magnitude, and in the same direction, but still statistically insignificant. In the overall sample and the white sample, the effect of the income manipulation is now smaller and statistically insignificant, but still in the expected direction. However, we can also not reject that the income effect is the same in Biloxi and Slidell. There is one anomalous finding from this row: the income manipulation has a significant positive effect among blacks, which is in the opposite direction from the income effect among whites. 
The fifth row is like the first except that it drops the demographic controls. These results are very similar to the results in the first row. The sixth row is like the first except that it adds extra controls which include subjective assessments of the effectiveness of Habitat for Humanity, how much the respondent values helping others, and how much the respondent cares about money. The results of this row are very similar to the results of Row 1. The seventh row is like the first except that it presents censored regressions instead of ordinary least squares regressions. These results are roughly similar to the results in Row 1.

Row 8 addresses concerns that the blue pictures used in our DD estimator might affect our results for unanticipated reasons. Table 1 already addresses this point to some extent by showing that average offers did not differ noticeably in the blue and blur treatment conditions. Row 8 shows that when we do not use the DD estimator and instead use only the sub-sample of respondents who saw blurred photos where the victims' race shows through, we get roughly the same results as in row 1 but with 37\% smaller standard errors on the picture manipulation.

These robustness checks confirm that there is no significant effect of the race manipulation; in none of the regressions is the coefficient on Black pictures $\times$ Blurred statistically significant. By and large, the table also confirms that respondents give more to victims in economically disadvantaged cities. The coefficient on the income manipulation is significant everywhere except for Biloxi and among black respondents.

\section{Effects of Treatments on Giving by Sub-groups}

In the results so far, we examined whether Americans on average give more or less depending on the race of the recipients, and found no evidence of such an effect. It is conceivable, however, that this lack of an average effect masks reactions in opposite directions by subgroups of the population. In this section, we test for differences in reactions by various types of subgroups. 


\subsection{Testing for Racial Group Loyalty}

Seeing pictures of black recipients might increase giving among black respondents but decrease giving among white respondents. In columns 1 and 2 of Table 4, we test for such racial group loyalty effects, i.e., whether respondents give more when the recipients belong to the same racial group as the respondent. These regressions use the samples of white and black respondents only.

In column 1, we estimate racial group loyalty using a triple difference: we compare the DD estimate of black picture race on giving by black respondents to the DD estimate of black picture race on giving by white respondents. We find that blacks give about $\$ 9.6$ more in response to black pictures than white respondents do, but this estimate is not statistically significant.

The triple difference estimate allows for black and white respondents to react differently to the backgrounds of the pictures. In column 2, we impose the assumption that the backgrounds of the pictures have the same effect on giving for respondents from different racial groups. If this assumption is valid, we can estimate racial group loyalty more precisely using a DD estimator that compares the difference in giving by respondent race to blurred black pictures to the difference in giving by respondent race to blurred white pictures. Thus, this DD estimator is only based on the sub-sample of respondents that saw blurred pictures. For the DD estimator, we find that blacks respond no differently to black pictures than white respondents. Overall, we believe that the estimates provide little support for racial group loyalty in the context of assistance to Katrina victims, though we recognize that the standard errors are sizeable.

\subsection{Addressing Race Salience}

We tried not to make it obvious to respondents that our study was in part about race (by not mentioning race or asking questions about race until the last section of the survey). However, some respondents undoubtedly correctly guessed that our study was partly about race. Thus, one possible interpretation of the result that giving does not seem to be influenced by the victims' race is that respondents may have changed their behavior because they did not want to appear racially biased (or see themselves as racially biased). This would not invalidate the results - on the contrary, it would suggest that knowledge that a certain behavior could be racially biased 
would reduce racial bias in that behavior. Still, it is interesting to know whether such a mechanism underlies our results on giving.

Ideally, we would like to eliminate any awareness among respondents that our study is about race. However, this is impossible, partly because of media coverage that links Katrina to race relations in the minds of many people. Instead, we chose to increase the salience of race. We did this by altering our main instrument in two ways. First, in the opening screen, we told respondents that they participated in a study on "Hurricane Katrina, race relations, and whether the race of Katrina victims mattered for how America responded to Katrina." To drive this point home, we asked about race perceptions immediately after the slide presentation and before the question on giving. Because we are estimating the effect of the race of Habitat recipients in the race-salient instrument relative to that in the regular instrument, all pictures in the race-salient instrument were blurred (and none were blued). We administered the race-salient instrument only to non-black respondents because we would expect social desirability concerns to be most relevant for them.

Column 3 of Table 4 shows how respondents' giving is affected by making race more salient. This regression is estimated using the sample of white respondents. The coefficient on Black pictures $\times$ Race salient $\times$ Blurred (Row 4) shows the difference between the effect of seeing blurred black pictures (rather than blurred white ones) in the race-salient instrument compared to the main instrument. The estimate is negative, though statistically insignificant, in the overall sample. Thus, if anything, respondents seem to give less in response to black pictures when race is more salient, which is the opposite of what we would have expected to find if social desirability were partly driving our estimates on giving from the main sample.

\subsection{Addressing Low Stakes}

Another way of reducing the effect of social desirability is to make it more costly to give the socially desirable answer. Rather than having a $10 \%$ chance of having their giving decision implemented, the respondents receiving the full-stakes version of our instrument had their decision implemented for sure. This instrument also addresses potential concerns about the validity of results from decisions that only have a probability of being pay-off relevant. In order to make the $\$ 100$ more "real" in the minds of the respondents, we gave them the $\$ 100$ at the 
beginning of the instrument, before the slide show. After the slide show, we told them they could give away part of their $\$ 100$ to Habitat for Humanity to help Katrina victims. The fullstakes instrument only contained blurred pictures and was administered only to non-blacks.

Column 4 of Table 4 compares giving in the full-stakes instrument to giving in the main version. The coefficient on Black pictures $\times$ Full stakes $\times$ Blurred (in Row 5) shows the effect of the full-stakes instrument on the amount respondents give in response to blurred black pictures rather than blurred white pictures. Respondents give slightly more in response to black pictures when the stakes are higher, but this effect is not statistically significant. Thus, we find no indication that our findings on race were driven by it being cheap in expected value for respondents to conceal a racial bias in giving.

However, larger stakes in combination with getting the money earlier in the survey do significantly reduce the average level of giving. In Table 4, the effect of being in the full-stakes treatment was about $\mathbf{- \$ 1 9}$. In unreported summary statistics, the average offer from white respondents in the full-stakes treatment was about $\$ 55$. In comparison, the average offer from whites in the main treatment was about $\$ 69$. This difference is significant at the one-percent level according to the Mann-Whitney test. The substantially lower offer in the full-stakes treatment could be due to the difference in the stake size. It could also be due to a stronger endowment effect because respondents were told about their endowment sooner in the full-stakes survey instrument than in the main instrument.

\subsection{Testing for Heterogeneity in Racial Bias Among Whites}

We test for heterogeneity in racial bias in two types of subgroups of whites. First, we test for interaction effects with all of our measures of race relations, of which there are three. One of these is a measure of ethnic closeness that comes from data collected by Knowledge Networks prior to our study. This question reads: "How close do you feel to your ethnic or racial group? Very close, close, not very close, not close at all." The other two come from our survey instrument (see Appendix A for exact wording). One measures the frequency of social contact with blacks minus the frequency of social contact with whites. The other measures perceptions about the prevalence of economic opportunities for blacks compared to whites, which we included in the survey as a self-reported measure of racial bias. Second, we test for interactions 
with select demographic variables that one might have expected to interact with our race manipulation. These demographics are living in the South, age, education, and political party identification.

Table 5 summarizes these results for the sample of whites. For expositional ease, we collapse those interaction variables that are not already dummies into dummy variables with about half of the respondents in each category. These interaction dummies are each interacted with our race and income manipulations. In unreported results, we find that the results of this table are very similar when we interact all of the independent variables with each of these interaction dummies in turn.

Row 1 of Table 5 presents the interaction results for the ethnic closeness dummy. There is a strong interaction between ethnic closeness and our race manipulation, and no significant interaction between ethnic closeness and the income manipulation. Whites who report to be "close" or "very close" to their ethnic or racial group give roughly $\$ 17$ less when seeing pictures with black victims rather than white ones. In contrast, whites who say they are "not very close" or "not close at all" give roughly $\$ 13$ more in response to pictures with black victims. These two coefficients are significantly different from each other at the $1 \%$ level. ${ }^{19}$

In unreported analyses, we find that the interaction between ethnic closeness and our race manipulation is very robust. For example, when we conduct four separate regressions for each response category of ethnic closeness, there is a clear pattern of heterogeneity according to ethnic closeness. Among those who are, respectively, "not close at all", "not very close" "close" and "very close" to their ethnic or racial group, the racial biases are \$26 (significant at the tenpercent level), $-\$ 4,-\$ 9$, and $-\$ 33$ (significant at the five-percent level). Furthermore, when ethnic closeness is measured as a continuous variable, it has a highly significant (at the one-percent level) negative interaction with the race manipulation. Interestingly, black respondents exhibit

\footnotetext{
${ }^{19}$ We also examined interaction effects of ethnic closeness and the race manipulation on perceptions of the racial composition of recipients (See Appendix C and Appendix Table A.4, panel D for details). We found that whites who say they are "close" or "very close" to their ethnic or racial group do not report perceiving a higher fraction of blacks in the black manipulation, despite giving significantly less in response to pictures with black victims. In contrast, whites who say they are "not very close" or "not close at all" to their ethnic or racial group report perceiving a higher fraction of blacks in the black manipulation and give significantly more in that case. These results are significantly different from each other at the $1 \%$ level. This finding is consistent with the idea that respondents report perceptions that increase the social desirability of their actions; they admit to seeing more blacks in the black treatment condition when they give more in response to pictures with black victims but not when they give less.
} 
the opposite pattern - for them the interaction between ethnic closeness and the race manipulation shows a positive effect on giving (significant at the $10 \%$ level).

We also investigated whether ethnic closeness is predicted by demographic variables. The main predictors are living in the South, which has a highly significant positive effect on ethnic closeness, and income, which has a significant negative effect on ethnic closeness. We find that the predicted values of ethnic closeness from this equation have a strong negative interaction (significant at the one-percent level) with the race manipulation.

One possible explanation for the ethnic closeness interaction is that social identity matters and race by itself does not adequately capture social identity. Whites on average do not discriminate significantly against blacks, and blacks on average do not discriminate significantly in favor of blacks. However, whites and blacks who identify with their ethnic or racial group do indeed display this behavior. Thus, what seems to matter is whether or not one identifies with a racially white or black ethnic group rather than simple measures of race. This makes sense in view of the rich array of social experiences that accompany inter-racial and inter-ethnic families, educations, and neighborhoods. Our results are consistent with Hungerman's (2006) finding that the charitable activity of all-white religious congregations decreases as the fraction of blacks in the community increases, if one believes that the members of all-white churches in Hungerman's study are similar to the ethnically close whites in our study.

Row 2 of Table 5 presents the interaction results for beliefs about economic opportunities for blacks. This measure had no significant interactions with the race or income manipulations. One might have expected those who perceive more opportunities for blacks to discriminate more against blacks. However, if it is socially undesirable to say that blacks have more opportunities, those who discriminate against blacks may censor their answers to the question on opportunities for blacks.

Row 3 presents the interaction results for the dummy measuring frequency of social contact with blacks relative to whites. Whites who report having equal or more social contact with blacks give about \$18 less in response to pictures with black victims while those who have less social contact with blacks give about $\$ 3$ more in response to pictures with black victims. These two effects are significantly different from each other at the five-percent level. When the continuous measure of social contact with blacks minus social contact with whites is used, its interaction with the race manipulation is negative and significant at the ten-percent level. Prior 
results on the effect of social contact on racial prejudice are mixed and suggest that it depends on the quality of social contact. Sociologists have argued that social contact may increase whites' prejudice against blacks if the contact makes them feel threatened while in other circumstances, such as when whites feel close to blacks, social contact can decrease whites' prejudice against blacks (Dixon, 2006). Much of this literature is based on non-causal evidence, though Hopkins (2007) finds evidence that communities that took in Katrina evacuees generally became less supportive of the poor, African Americans and policies to help those groups compared to otherwise similar communities that did not receive evacuees. On the other hand, recent findings show that inter-racial social contact among randomly assigned college room-mates increases cross-racial empathy (Boisjoly et al., 2006), lending support to the idea that friendly inter-racial contact decreases racial prejudice. In our data, unreported analyses suggest that among whites, high levels of social contact with blacks relative to contact with whites is significantly associated with living in the South and having a lower income. Thus, one possible interpretation of our results is that poor Southern whites who report relatively more social contact with blacks also feel unfriendly toward blacks and discriminate against them in our experiment. Note that this is not causal evidence; our measure of social contact might simply identify prejudiced whites if, for any given level of social contact with blacks, prejudiced whites feel or perceive this contact more strongly.

To summarize, Panel A shows a strong effect of ethnic closeness on racial bias; whites who are close to their ethnic group discriminate against blacks and whites who are not close to their ethnic group discriminate in favor of blacks. Our measure of ethnic closeness was collected by Knowledge Networks prior to our study, making it a particularly clean measure of racial attitudes. The other two measures were collected in our survey after respondents decided how much money to give and may thus be influenced by the respondent's decision about how much to give.

Panel B of Table 5 presents interactions between selected demographic variables - namely, living in the South, age, education and political party affiliation - and the recipient race manipulation. One might expect whites from the South to discriminate differently from whites from the North for historical reasons, older people to discriminate differently from younger people because of social change, and educated people to discriminate differently because of possible effects of education on social values. However, we find that none of these demographic 
variables have significant interactions with the race manipulation. Age has a negative interaction with the income manipulation: people who are 50 or older give about $\$ 9$ less when told that the city is economically advantaged, while people under 50 give only $\$ 3$ less. These effects are statistically different from each other at the ten-percent level. Row 7 shows that there is no significant interaction between political party affiliation and the race manipulation.

\section{Comparisons Across Measures of Generosity}

In this experiment, we went to considerable length and expense to create a measure of generosity that is based on behavior because of concerns that self-reported or hypothetical measures of generosity are more susceptible to pressure to provide socially desirable answers. Nonetheless, subjective measures are often the best feasible measures of certain concepts, including support for public spending. Furthermore, it is interesting to examine how actual giving in our experiment compares to subjective and hypothetical measures of private generosity.

Table 6 presents the effects of the experimental manipulations on actual giving and the three self-reported measures of generosity contained in our survey. Each row presents results from a single regression. The first three sets of rows present the regressions that explain our three measures of private generosity: actual giving in the experiment, hypothetical giving, and subjective support for charitable giving to Katrina victims in the small city in question. We ask about hypothetical giving because it measures behavior in a setting that is more natural (giving with own money in response to a mail solicitation). While the external validity of this measure may therefore be greater, it has the drawback that it measures hypothetical rather than actual behavior. The wording of the question that measures subjective support for charitable assistance to Katrina victims is very similar to our question that measures subjective support for government spending to help Katrina victims. This question thus enables us to compare determinants of private and public generosity without confounding it with the method of measuring generosity. The fourth set of rows presents regressions explaining our measure of public generosity, namely subjective support for government spending to help Katrina victims in the small city. For each measure of generosity, there is a regression for the whole sample, the 
sample of white respondents, and the sample of black respondents. It is striking that the explanatory power for the regressions of actual giving is higher than the explanatory power for any of the hypothetical or subjective measures of generosity. This is consistent with subjective or hypothetical measures being measured with more noise.

The first three columns present the estimated effects of the race manipulation, the income manipulation, and the degree to which the respondent was manipulated to perceive the victims as deserving. This deservingness variable was constructed by adding the dummies for the audio manipulations intended to increase perceived deservingness (victims helped others in need, prepared for the hurricane, and will contribute labor to building their own home from Habitat and to the homes of other recipients) and subtracting the dummy for the audio manipulation intended to decrease perceived deservingness (crime is a problem in the city). ${ }^{20}$

None of these effects were significant in regressions explaining private generosity, except for the negative effect of recipient income - already discussed above - on giving in the whole sample and the white sample. In contrast, there is a highly significant positive effect of perceived deservingness on subjective support for public assistance to Katrina victims in the city in question in the overall sample and sample of white respondents. We also find a significant negative effect of the black picture manipulation among whites. White respondents show significantly less support for government spending on Katrina victims in the city in question when they are in the black picture manipulation rather than the white picture manipulation.

These results are consistent with the literature on determinants of support for public redistribution which has shown that both race and perceptions of deservingness play important roles. ${ }^{21}$ In view of the strong effects of race and deservingness in support for public assistance, the fact that they have no significant effects on private generosity may seem surprising. One possible explanation is that respondents believe that Habitat for Humanity chooses to help only

\footnotetext{
${ }^{20}$ In constructing this variable, we did not include our manipulations on church attendance, use of public assistance, or looting in the city. Church attendance may be seen as a positive or a negative trait, depending on the respondent's views. Use of public assistance confounds possible judgments of deservingness with judgments of need. Finally, we did not include the looting manipulation because we originally included it to prime subjects with a racially charged issue. Obviously, the looting manipulation may have affected perceptions of deservingness, so it is worth mentioning that our results are very similar if we include the looting manipulation in our measure of deservingness.

${ }^{21}$ See, for instance, Luttmer (2001) on racial group loyalty and Fong (2001) and Corneo and Grüner (2002) on fairness, and Alesina, Glaeser and Sacerdote (2001) for a review.
} 
deserving individuals, while the government does not. Some of the open-ended comments that we received also hint at this. For example, one respondent wrote: ${ }^{22}$

"The people who receive help from Habitat are hard-working families, but the people on public assistance seem to be several hundred pounds overweight. I have trouble putting food on my table and [paying my] expenses. These people are living high on the hog at our expense."

If such sentiments are widespread, then beliefs about the average level of deservingness among victims may be pertinent for public assistance but not for private charity. This difference in beliefs about recipients of charity and recipients of government assistance could also explain the presence of a race effect in public generosity to Katrina victims and its absence in private generosity, if the effect of race operates through perceptions of deservingness, as some have argued (Gilens, 2001).

6. Possible Concerns Regarding the Validity of the Experiment

In addition to the strengths and limitations of our study already discussed above, there are additional concerns about the validity of our experiment that we can now address by considering the above results as a whole and by further examining the relationship between giving in the experiment and self-reported prior charitable giving.

One concern might be that the lack of a significant race effect on average giving is due to a weak manipulation of race perceptions. However, our race manipulation had highly significant effects in three cases. First, it had a highly significant effect on perceptions of the racial composition of victims (see Appendix C). Second, it had highly significant, but heterogeneous, effects on giving that are masked in the average giving. Third, it had significant effects on subjective support for government assistance to the Katrina victims. So, while it is possible that

\footnotetext{
${ }^{22}$ Other notable quotes expressing similar sentiments are: "It has been my experience that the government from the feds to the local city and county government are inept and corrupt and give people who are capable of working money and food for not working. People who will not work should not have children and should not be fed, housed or clothed by government or charity. You don't work, you don't eat. But for those who cannot work or are widows and orphans, charities and churches should provide for them." and "I know that there are a lot of stereotypes, but I really do think that the government has tried to help people with welfare, etc, and yet it got out of hand, mismanaged, and ultimately made people dependent on the assistance. .... I don't think that there is an easy answer, but on the other hand, I don't think that Welfare is it. I applaud Habitat for Humanity who does very good work and gives people self-respect."
} 
an even stronger race manipulation may have affected giving on average, the manipulation was strong enough to produce the variety of effects just summarized.

Another concern is that our measure of giving may not be a valid measure of generosity to Katrina victims: it may either be too noisy or may measure something else (such as guilt or concerns about pleasing the investigators). Several findings suggest that giving in our experiment is a valid measure of generosity to victims. First, the findings that giving i) responds to the income of Katrina victims, ii) responds strongly, albeit heterogeneously, to the race manipulation, and iii) is strongly predicted by past charitable behavior, rule out the possibility that our measure is merely noise. We further investigate the validity of our giving measure by comparing its sensitivity to socioeconomic variables against the sensitivity of prior charitable giving to the same demographic variables. We find that giving in our experiment is $55 \%$ to $85 \%$ as sensitive to demographic characteristics as self-reported prior charitable giving. ${ }^{23}$

Thus, our validity analysis suggests that giving in the experiment responds to the same kinds of factors that affect charitable giving in the natural world. However, these findings do not tell us how realistic the level of giving is in our dictator game (although we can say that the level of giving is high relative to certain benchmarks, such as giving in standard laboratory dictator games conducted on college students). There is little reason to believe that the level of giving in our experiment measures the marginal propensity to give out of income. Instead, it is a behaviorbased measure of how much people care about some types of Katrina victims relative to others.

\section{Conclusion}

In this experiment, we manipulated the perceived income, deservingness, and race of Katrina victims in order to estimate how these factors influence actual giving to Katrina victims and

\footnotetext{
${ }^{23}$ First, we create a comparable measure of total charitable in 2005 giving by top-coding it at a value such that the same percentage of respondents are top-coded in both measures, and then normalizing total charitable giving so it ranges from zero to 100 . We then use the available demographic variables to create predicted values of giving to Katrina victims in our experiment and predicted values of total charitable giving in the prior year. We then regress giving in our experiment on predicted total charitable giving, and also regress total charitable giving on predicted giving in the experiment. We get large t-statistics - roughly 12 and 15, respectively. According to the coefficient in the first regression, giving in our experiment is $55 \%$ as sensitive to demographic characteristics as is total charitable giving. The second regression suggests that giving in our experiment is $85 \%$ as sensitive to demographic characteristics. The difference in these two sensitivity estimates is due to the fact that the linear combinations of the demographic characteristics constituting the two predicted variables are not exactly equal.
} 
subjective support for government spending to help Katrina victims. We have three main findings concerning actual giving. First, the income of recipients matters; people give more when they are manipulated to perceive the recipients as relatively poor. Second, neither the race nor deservingness manipulations have a significant effect on giving in our experiment. Third, masked by the averages are substantial differences in racial bias across sub-groups of our sample. For instance, we find that whites who feel close to their ethnic or racial group display substantial bias against blacks while whites who do not feel close to their ethnic or racial group display substantial bias in favor of blacks. We have analogous findings for black respondents. This might indicate that social identity is an important predictor of racial bias, but that race by itself is not a good proxy for social identity. We find that the determinants of subjective support for public assistance appear to be different. Both race and deservingness have significant effects on measures of support for government spending to help Katrina victims, while the income of recipients has no significant effect.

The insignificant effects of race and deservingness on giving are not due to a weak manipulation of perceptions of the corresponding characteristics of the victims. Nor should it be interpreted as meaning that racial bias and perceptions of deservingness are less important than previously thought. Instead, our results suggest that the determinants of generosity can differ substantially across the different types of institutions that provide assistance. The reasons for this are poorly understood, but one possible mechanism may be differences in the extent to which these institutions are perceived to pre-select deserving recipients. Thus, we believe that research on the specific conditions that do and do not elicit biases according to race and perceived deservingness would be especially useful. 


\section{Appendix A: Survey Instrument}

- Text that is notes is bold and in brackets. Text that is the name of a question or a variable name is in brackets and capital letters.

- Audio text that respondents hear is in italics; all other text the respondents read.

- For multiple choice questions, respondents were given radio buttons to click on. In this appendix, this shows up as numbered options [1], [2], [3].

- Separating lines correspond to new screens.

[CITY] was replaced in both the text and the audio with either the word "Biloxi" or the word "Slidell" depending on the version.

\section{- Main Questionnaire -}

This is a study conducted by researchers at Carnegie Mellon University and Harvard University. The general topic is Hurricane Katrina and other issues facing America.

THANK YOU FOR YOUR PARTICIPATION!

\section{[PART I. BACKGROUND ABOUT A SMALL CITY AFFECTED BY HURRICANE KATRINA]}

\section{Presentation about Hurricane Katrina}

Shortly, you will see a brief presentation about the effects of Hurricane Katrina on a small town. However, first we would like to know, how closely did you follow the news about Hurricane Katrina and its aftermath?

Very closely (e.g., watching TV, listening to the radio or reading news about Katrina for more than an hour a day during the week following the hurricane) .................................... 1

Quite closely (e.g., watching TV, listening to the radio or reading news about Katrina for about 31-60 minutes a day during the week following the hurricane) ................................... 2

Somewhat closely (e.g., watching TV, listening to the radio or reading news about Katrina for about 10-30 minutes a day during the week following the hurricane) .................. 3

Not too closely (e.g., watching, listening to, or reading headline news for a few minutes a day for one or more days during the week following the hurricane) .................................... 4

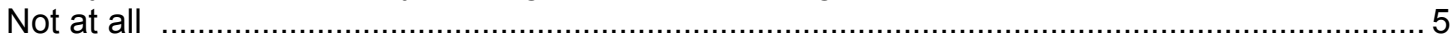

Though you may already have seen quite a bit of media coverage about Katrina, much of the coverage focused on the effects of Katrina on New Orleans and its residents. However, many small towns and cities were also affected, and they differ in many ways from New Orleans. Next you will see a short presentation about the effects of Hurricane Katrina on a small city called [CITY].

Please have the volume on your computer or TV adjusted so that you can clearly hear the speaker's voice that goes with the slides.

To respect their privacy, we have obscured the identities of the people shown in the slides.

During the presentation, the "Continue" button only becomes active after the speaker has finished.

[Respondents view first pair of pictures and hear following audio text] Effects of Katrina on [CITY]

As you may know, Hurricane Katrina hit the Gulf coast on August $29^{\text {th }}, 2005$. While the devastation in New Orleans received the most media coverage, many small cities in Louisiana and Mississippi were also affected. Here we show you some of the effects of Katrina on the residents of the small city of [CITY]. Contrary to what many people believe, this city differs in many ways from New Orleans, such as in terms of the make-up of the population or the effects of Katrina. 
[REPUBLICAN]:

$0 . \quad$ [NO INFORMATION CONDITION]

1. For example, while New Orleans votes overwhelmingly Democratic, Republicans have a solid majority in [City].

[Respondents view second pair of pictures and hear following audio text]

The Residents of [CITY]

[RECEIVED GOVERNMENT ASSISTANCE PRIOR TO KATRINA]:

Katrina also caused financial hardship for the residents of [CITY]. Many business operations had to close, and postal service to the area was interrupted for a long time.

0 . As a result, many employees stopped receiving their pay-checks.

1. As a result, many recipients of government assistance stopped receiving their benefit checks.

[ECONOMICALLY ADVANTAGED]:

[Manipulation for Biloxi:]

-1. Economically, Biloxi is relatively disadvantaged. Prior to Katrina, its median household income was well below the national average and its poverty rate was 18 percent higher than the rest of the country.

$0 . \quad$ [NO INFORMATION CONDITION]

[Manipulation for Slidell:]

$0 . \quad$ [NO INFORMATION CONDITION]

1. Economically, Slidell is relatively well-off. Prior to Katrina, its median household income was above the national average and its poverty rate was 5 percent lower than the rest of the country.

[CRIME]:

$0 . \quad$ This city has mostly law-abiding citizens.

1. This city has been troubled by crime and drug abuse.

[CHURCH ATTENDANCE]:

0. Many residents do not attend church on Sunday.

1. Many residents attend church on Sunday.

[CHURCh ATtendANCE AND CRIME MANIPULATIONS WERE COMBINED INTO ONE SENTENCE, SUCH AS "THIS CITY haS BEEN TROUBLED BY CRIME AND DRUG ABUSE, AND MANY RESIDENTS DO NOT ATTEND CHURCH ON SUNDAY."]

[RESPONDENTS VIEW THIRD PAIR OF PICTURES AND HEAR FOLLOWING AUDIO TEXT]

Reactions to Hurricane Katrina in [CITY]

In [CITY], there were a variety of reactions to the hurricane.

[WILLING TO HELP OTHERS]:

0 . When the threat of the Hurricane became clear, many residents became mostly concerned about their own situation and did not help others in need.

1. When the threat of the Hurricane became clear, many residents became concerned about the situation and helped others in need.

[MENTION OF LOOTING]:

$0 . \quad$ [NO INFORMATION CONDITION]

1. In the aftermath of Katrina, looting and lawlessness were a concern.

Habitat for Humanity, a non-profit charity, has stepped in to help those in need of decent housing.

[RESPONDENTS VIEW FOURTH PAIR OF PICTURES AND HEAR FOLLOWING AUDIO TEXT]

Habitat for Humanity in [CITY]

[PREPARES FOR HURRICANES]:

0. Partly because many residents underestimated the risk of hurricanes, Katrina did considerable damage.

1. Even though many residents took reasonable precautions against hurricanes, Katrina did considerable damage. 
Fortunately, [CITY] has its own local chapter of Habitat for Humanity which helps build housing for people in the community who need it. Families moving into these homes experience an improvement in housing conditions that they could not have attained by themselves.

[SWEAT EQUITY]:

$0 . \quad$ [NO INFORMATION CONDITION]

1. In return, they must invest at least 300 hours of labor - so-called "sweat equity" - into building their own homes plus homes for other families.

[SOUND CHECK] How well could you hear the speaker's voice in the presentation you just saw?

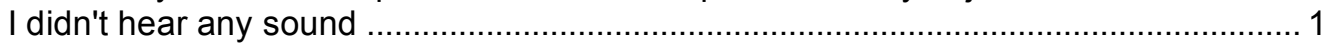

I heard some sound but couldn't understand what she was saying ............................. 2

The speaker's voice was clear and understandable .................................................... 3

[IF RESPONDENT SELECTS 1 ("DIDN'T HEAR ANY SOUND") OR 2 ("COULDN'T UNDERSTAND WHAT SHE WAS SAYING") IN CHECK, SURVEY SKIPS TO DISPLAY SCREEN AT THE BEGINNING OF PART IV.]

\section{[PART II. DECISION-MAKING TASK]}

Decision-making task

Now, you are going to make a decision about assistance to Katrina victims in [CITY]. Please note that all information we give you is true and all payments will be made exactly as stated. Please think carefully about your decision because one out of every 10 participants in this study will have his or her decision carried out with real money.

We will give $\$ 100$ to one out of every 10 participants in this study. We ask you to decide in advance how much of this $\$ 100$, if any, you would like to give to the local chapter of Habitat for Humanity in [CITY]. You can give any amount you wish, including nothing. If you are selected, this $\$ 100$ is yours, and you are free to keep or to give away any amount you wish, including nothing. While many people give some away, we expect that most people will keep at least some of this amount for themselves.

If you are randomly selected to receive $\$ 100$, we will send the amount that you want to donate, if any, to the local Habitat for Humanity chapter in [CITY]. The amount that you decide to keep for yourself will be credited to your Knowledge Networks account (you get 1000 bonus points for each dollar you decide to keep).

If you decide to donate money, Habitat for Humanity in [CITY] will mail you a note to confirm that we sent them exactly the amount you specified.

The random selection works as follows. If the first number of the Pick3 draw of the Louisiana State Lottery on June 23, 2006 is [LOTTERYNUmBer], then we will carry out your decision. Because numbers in the Pick3 game lie between 0 and 9 , you have a 1 in 10 chance that we will carry out your decision. If you wish, you will be able to find the winning number on http://www.louisianalottery.com. However, this is not necessary. If your number is drawn, we will automatically carry out your decision.

[GIVING] Now, please decide how much of your $\$ 100$ you want to give to Habitat for Humanity for Katrina victims in [CITY] in the event that you are randomly selected to receive $\$ 100$.

If the first number of the Pick3 draw on June 23, 2006 is [LOTTERYNumBer],

I want \$__ to be sent to Habitat for Humanity to help victims of Hurricane Katrina in [CITY].

[IF THE RESPONDENT DID NOT ENTER A NUMBER FROM 0 TO 100 THEY WERE GIVEN THE MESSAGE: "YOU HAVE ENTERED AN INVALID NUMBER. PLEASE ENTER A NUMBER FROM \$0.00 TO \$100.00”] 
[CONFIRM] If the first number of the Pick3 draw on June 23, 2006 is [LOTteRYNumber], \$[AMOUNT FROM ABOVE] will be sent to victims of Hurricane Katrina via Habitat for Humanity in [CITY], and \$[100 - AMOUNT FROM ABOVE] will be sent to you as a credit of [1000*REMAINDER] bonus points to your Knowledge Networks account.

Is this correct?

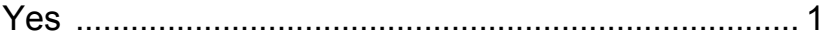

No, I would like to change my answer.................... 2

[SHOWN GIVING AGAIN IF RESPONDENT SELECTED “No” IN CONFIRM]

\section{[SHOWN FOLLOWING IF GIVING=0]}

[HYPOTHETICAL GIVING]:

Suppose that Habitat for Humanity in [CITY] had mailed a letter to your home describing the effects of Katrina on [CITY] and had asked you for a donation. How much, if anything, would you have given?

[GIVEN A NUMBER BOX WITH A RANGE 0-99999]

\section{[SHOWN FOLLOWING IF GIVING>0]}

[HYPOTHETICAL GIVING]:

Suppose that you had not just given \$[GIVING] to Habitat for Humanity. Instead, suppose that Habitat for Humanity in [CITY] had mailed a letter to your home describing the effects of Katrina on [CITY] and had asked you for a donation. How much, if anything, would you have given?

[GIVEN A NUMBER BOX WITH A RANGE 0-99999]

\section{[PART III. QUESTIONS ABOUT [CITY]]}

Factual questions about Katrina

From the information presented earlier, you may have learned more about [CITY]. Now, we'd like to ask you some questions about [CITY] and about the characteristics of Katrina victims who receive aid from Habitat for Humanity in [CITY].

It is very important to us that you answer these questions as carefully as possible. We will give you 1500 bonus points for completing this section of the study. In return, we would appreciate it if you would put in extra effort to answer these questions as carefully as possible.

[WINDSPEED]: First, we'd like to know how severe you thought Hurricane Katrina was when it hit [CITY]. Note that, by definition, the maximum sustained wind speeds of category 1-5 storms are as follows: 74-95 mph for category $1,96-110 \mathrm{mph}$ for category $2,111-130 \mathrm{mph}$ for category $3,131-155 \mathrm{mph}$ for category 4 , and $156 \mathrm{mph}$ or more for category 5.

What do you think was the maximum sustained wind speed in [CITY] when Katrina hit?

74-95 mph (Category 1 hurricane).

96-110 mph (Category 2 hurricane)

111-120 mph (Category 3 hurricane)

121-130 mph (Category 3 hurricane)

131-139 mph (Category 4 hurricane)

140-155 mph (Category 4 hurricane)

156-169 mph (Category 5 hurricane)

$170 \mathrm{mph}$ or greater (Category 5 hurricane)

[FOR EACH OF THE FOLLOWING QUESTIONS RESPONDENTS WERE GIVEN A NUMBER BOX WITH A RANGE 0 TO 100]

[INCOME OF HABITAT FOR HUMANITY RECIPIENTS]. 
We'd like to know what you think the median household income is for recipients of Habitat for Humanity in [CITY]. The median (i.e., middle) household income is the income where half of the Habitat households are richer and half are poorer.

As a reference, the Federal poverty standard is currently about $\$ 20,000$ for a family of 4 , and exactly half of all households in the U.S. have an income less than $\$ 44,000$ per year

My best guess is that the median household income of recipients of Habitat for Humanity in [CITY] is about \$ ,000 per year.

[PERCENT OF RECIPIENTS WILLING TO WORK HARD]:

As your best guess, what percentage of recipients of Habitat for Humanity in [CITY] are willing to work hard in order to get ahead in life?

[PERCENT OF RECIPIENTS WITH A CRIMINAL RECORD]:

As your best guess, what percentage of recipients of Habitat for Humanity in [CITY] have a criminal record?

\section{[PERCENT OF RECIPIENTS WHO ATTEND CHURCH]:}

As your best guess, what percentage of recipients of Habitat for Humanity in [CITY] attend religious services almost every week?

[PERCENT OF RECIPIENTS WHO PREPARED FOR HURRICANE]:

As your best guess, what percentage of recipients of Habitat for Humanity in [CITY] prepared as well as one can reasonably expect for Hurricane Katrina?

\section{[PERCENT OF RECIPIENTS HELPING OTHERS]:}

As your best guess, what percentage of adult recipients of Habitat for Humanity in [CITY] helped fellow hurricane victims when the threat of the Hurricane became clear?

[PERCENT OF RECIPIENTS WHO RECEIVED GOVERNMENT ASSISTANCE PRIOR TO KATRINA]:

As your best guess, what percentage of recipients of Habitat for Humanity in [CITY] received government cash assistance before Katrina hit?

[PERCENT OF RECIPIENTS WHO VOTED FOR BUSH]:

Now, we'd like to ask you about Habitat for Humanity recipients in [CITY] who voted in the 2004

Presidential election. As your best guess, what percentage of these people voted for George W. Bush?

\section{[Part IV. Survey Questions]}

\section{Survey Questions}

Now we'd like to ask you some survey questions about Hurricane Katrina and other issues. There are no right or wrong answers. Please simply answer the questions as truthfully as you can. 
Compared to the current level of spending, do you think the government should spend more or less of its budget on rebuilding and assistance to Katrina victims in [CITY]?

\begin{tabular}{|c|c|c|c|c|c|c|}
\hline $\begin{array}{c}\text { Government } \\
\text { should spend } \\
\text { much LESS }\end{array}$ & & $\begin{array}{c}\text { Government } \\
\text { should spend } \\
\text { the same }\end{array}$ & & & $\begin{array}{c}\text { Government } \\
\text { should spend } \\
\text { much MORE }\end{array}$ \\
\hline [1] & [2] & {$[3]$} & {$[4]$} & {$[5]$} & {$[6]$}
\end{tabular}

[SUBJECTIVE SUPPORT FOR CHARITY SPENDING TO HELP KATRINA VICTIMS IN CITY]:

Compared to their current level of spending, do you think that charities should spend more or less of their budgets on rebuilding and assistance to Katrina victims in [CITY]?

\begin{tabular}{|c|c|c|c|c|c|c|}
\hline $\begin{array}{c}\text { Charities } \\
\text { should spend } \\
\text { much LESS }\end{array}$ & & $\begin{array}{c}\text { Charities } \\
\text { should spend } \\
\text { the same }\end{array}$ & & & $\begin{array}{c}\text { Charities } \\
\text { should spend } \\
\text { much MORE }\end{array}$ \\
\hline$[1]$ & {$[2]$}
\end{tabular}

\section{[EFFECTIVENESS OF HABITAT FOR HUMANITY]:}

How effective do you think [City]'s local chapter of Habitat for Humanity is at getting aid to needy recipients? More specifically, out of every $\$ 100.00$ that is donated to it, how many dollars do you think go to needy recipients?

[RESPONDENTS GIVEN A NUMBER BOX WITH RANGE 0 TO 100]

\section{[EFFECTIVENESS AND SPEED OF GOVERNMENT RESPONSE]:}

Do you think the Federal Government responded as quickly and effectively as it should have to meet the needs of Katrina victims in [CITY]?

$$
\text { Yes... }
$$

No

\section{[GOVERNMENT CAPABILITY AND CARING]:}

To the degree that the response was inadequate, do you think the reason was primarily that the Federal Government did not care enough about the residents of [CITY] or that the Federal Government was not capable enough?

\begin{tabular}{|c|c|c|c|c|c|c|}
\hline $\begin{array}{c}\text { Government } \\
\text { did not care } \\
\text { enough }\end{array}$ & & & & & & $\begin{array}{c}\text { Government } \\
\frac{\text { was not }}{\text { capable }} \\
\text { enough }\end{array}$ \\
\hline$[1]$ & {$[2]$} & & & & {$[6]$} \\
\hline
\end{tabular}

[PERSONAL CONNECTION TO EVENT]:

Do you personally know someone who was injured or killed, lost property or had to evacuate because of Hurricane Katrina?

$$
\text { Yes........ }
$$

No

[PREFERENCES FOR SOCIAL SPENDING]: 
We are faced with many problems in this country, none of which can be solved easily or inexpensively. Below, we list two of these problems. For each one, please tell us whether you think we're spending too much money on it, too little money, or about the right amount.

Programs for the poor (e.g., "welfare" or programs like TANF, food stamps, and public housing)

\begin{tabular}{|c|l|l|c|l|c|}
\hline $\begin{array}{c}\text { Spending } \\
\text { too } \\
\text { LITTLE }\end{array}$ & $\begin{array}{c}\text { Spending } \\
\text { about the } \\
\text { right } \\
\text { amount }\end{array}$ & & & $\begin{array}{c}\text { Spending too } \\
\mathrm{MUCH}\end{array}$ \\
\hline
\end{tabular}
[1]
[2]
[3]
[4]
[5]
[6]
[7]

Social insurance programs (e.g., Social Security, Unemployment Insurance, and Medicare?).

\begin{tabular}{|c|l|l|c|l|c|}
\hline $\begin{array}{c}\text { Spending } \\
\text { too } \\
\text { LITTLE }\end{array}$ & $\begin{array}{c}\text { Spending } \\
\text { about the } \\
\text { right } \\
\text { amount }\end{array}$ & & & $\begin{array}{c}\text { Spending too } \\
\text { MUCH }\end{array}$ \\
\hline
\end{tabular}
[1]
[2]
[3]
[4]
[5]
[6]
$[7]$

[FOR THE FOLLOWING FOUR QUESTIONS RESPONDENTS WERE GIVEN NUMBER BOXES WITH A RANGE 0 TO 999999]

\section{[THE FOLLOWING WAS SHOWN IF SOUND CHECK=3, HEARD SPEAKER'S VOICE]}

[TOTAL PRIOR GIVING TO KATRINA RELIEF]:

Not including any amount you may have given during his survey, what, approximately, is the total amount of money that you and people in your household donated towards the Katrina relief effort?

$\$$

[THE FOLLOWING WAS SHOWN IF SOUND CHECK=1 OR 2, DIDN'T HEAR OR UNDERSTAND SPEAKER'S VOICE]

[TOTAL PRIOR GIVING TO KATRINA RELIEF]:

What, approximately, is the total amount of money that you and people in your household have donated towards the Katrina relief effort?

$\$$

[TOTAL GIVING TO CHARITIES FOR POVERTY IN 2005]:

What, approximately, is the total amount of money that you and people in your household have donated in 2005 to charities that help poor people in the U.S.?

$\$$

[TOTAL GIVING TO CHARITIES IN 2005]:

What, approximately, is the total amount of money that you and people in your household donated towards all charitable causes in 2005 ?

$\$$

\section{[REASONS FOR POVERTY]}

Now, we would like to ask you about some of the possible reasons why people are poor.

For each of the possible reasons listed below, please tell us how important you believe it is in explaining why some people in this country are poor.

Failure of society to provide good schools for everyone 


\begin{tabular}{|c|l|l|l|l|l|l|}
\hline $\begin{array}{c}\text { Not at all } \\
\text { important }\end{array}$ & & $\begin{array}{c}\text { Somewhat } \\
\text { important }\end{array}$ & & $\begin{array}{c}\text { Extremely } \\
\text { important }\end{array}$ \\
\hline
\end{tabular}

[2] [3]

[4]

[5]

[6]

[7]

Loose morals and substance abuse

Not at all
important

[1]

[2]

[3]

Somewhat
important

[4]

(2)

[5]

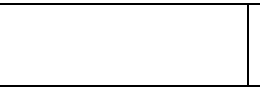

[6]
Extremely important

[7]

Failure of the economy to provide enough jobs

Not at all
important

[1]
[2]

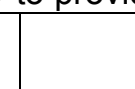

\section{Somewhat
important}

[4]
|

[5]
Extremely important

Lack of effort by the poor themselves

Not at all
important

[1]

[2]

[3]

\section{Somewhat \\ important}

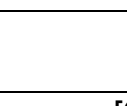

[6]

[7]

\section{[LIFE PRIORITIES]:}

There are many important things in life, but some are more important than others. We are going to ask you about the five most important things from the list below.

First, what do you believe is the most important?

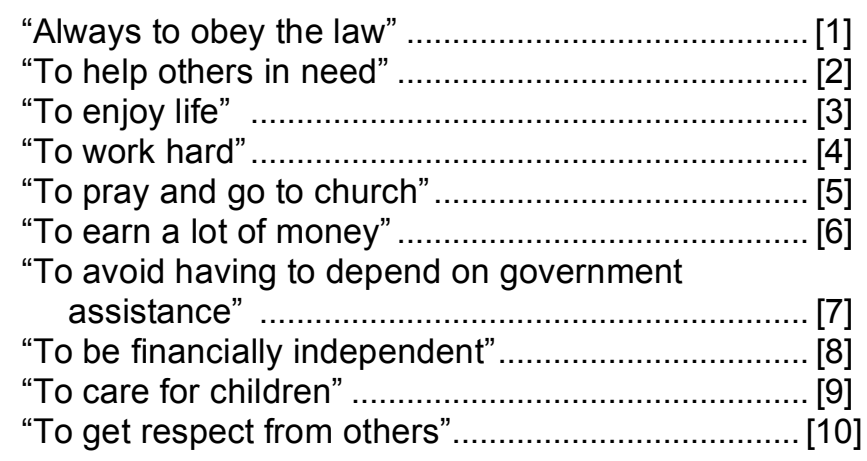

[LIFEPRIORITIES2]: What do you believe is second most important?

[SHOWN RESPONSES NOT SELECTED ABOVE]

[LIFEPRIORITIES3]: What do you believe is third most important?

[SHOWN RESPONSES NOT SELECTED ABOVE]

[LIFEPRIORITIES4]: What do you believe is fourth most important?

[SHOWN RESPONSES NOT SELECTED ABOVE]

[LIFEPRIORITIES5]: What do you believe is fifth most important?

[SHOWN RESPONSES NOT SELECTED ABOVE]

[FOR FOLLOWING TWO QUESTIONS RESPONDENTS WERE GIVEN NUMBER BOXES WITH RANGE 0 TO 100 SUMMING TO 100; WITH A SUM BOX FOR AMOUNTS ENTERED; THEY WERE WARNED IF THE PERCENTAGES WERE NOT EQUAL TO 100] 
[PERCENT OF RECIPIENTS WHO ARE [RACE]]:

As your best guess, what percentage of recipients of Habitat for Humanity in [CITY] are:

White? $\%$

African American?

Another race? $\%$

[PERCENT OF RESIDENTS WHO ARE [RACE]]:

As your best guess, what percentage of all residents of [CITY] are:

White? $\%$

African American?

Another race? $\%$ $\%$

[SOCIAL CONTACT WITH [RACE]]:

How often do you socialize with friends from the following racial and ethnic groups?

Caucasian Americans (Whites)

\begin{tabular}{|c|c|c|c|c|c|c|}
\hline Never & $\begin{array}{c}\text { Once a } \\
\text { year or less }\end{array}$ & $\begin{array}{c}\text { A few times } \\
\text { a year }\end{array}$ & $\begin{array}{c}\text { Once or } \\
\text { twice a } \\
\text { month }\end{array}$ & $\begin{array}{c}\text { Almost } \\
\text { every week }\end{array}$ & $\begin{array}{c}\text { Once a } \\
\text { week }\end{array}$ & $\begin{array}{c}\text { Everyday or } \\
\text { almost } \\
\text { everyday }\end{array}$ \\
\hline
\end{tabular}

[1]

[2]

[3]

[4]

[5]

[6]

[7]

African Americans

\begin{tabular}{|c|c|c|c|c|c|c|}
\hline Never & $\begin{array}{c}\text { Once a } \\
\text { year or less }\end{array}$ & $\begin{array}{c}\text { A few times } \\
\text { a year }\end{array}$ & $\begin{array}{c}\text { Once or } \\
\text { twice a } \\
\text { month }\end{array}$ & $\begin{array}{c}\text { Almost } \\
\text { every week }\end{array}$ & $\begin{array}{c}\text { Once a } \\
\text { week }\end{array}$ & $\begin{array}{c}\text { Everyday or } \\
\text { almost } \\
\text { everyday }\end{array}$ \\
\hline
\end{tabular}

[1]

[2]

[3]

[4]

[5]

[6]

[7]

People from other racial or ethnic groups

\begin{tabular}{|c|c|c|c|c|c|c|}
\hline Never & $\begin{array}{c}\text { Once a } \\
\text { year or less }\end{array}$ & $\begin{array}{c}\text { A few times } \\
\text { a year }\end{array}$ & $\begin{array}{c}\text { Once or } \\
\text { twice a } \\
\text { month }\end{array}$ & $\begin{array}{c}\text { Almost } \\
\text { every week }\end{array}$ & $\begin{array}{c}\text { Once a } \\
\text { week }\end{array}$ & $\begin{array}{c}\text { Everyday or } \\
\text { almost } \\
\text { everyday }\end{array}$ \\
\hline
\end{tabular}

[1]

[2]

[3]

[4]

[5]

[6]

[7]

\section{[PERCEIVED ECONOMIC OPPORTUNITIES OF AFRICAN AMERICANS]:}

Just in your opinion, how do the economic opportunities of African Americans compare to the economic opportunities of other Americans? Do African Americans get many fewer opportunities, about the same number, or many more opportunities than other Americans?

\begin{tabular}{|c|c|c|c|c|c|c|}
\hline $\begin{array}{c}\text { Many } \\
\text { FEWER }\end{array}$ & & $\begin{array}{c}\text { About the } \\
\text { same }\end{array}$ & & & Many MORE \\
\hline$[1]$ & {$[2]$} & {$[4]$} & {$[5]$} & {$[6]$} & {$[7]$} \\
\hline
\end{tabular}

[ITEMIZE DEDUCTIONS]:

Do you itemize deductions on your Federal taxes?

Yes

No .....

Don't know

[OPEN-ENDED STANDARD CLOSE] Thinking about this topic, do you have any comments you would like to share?

[OPEN-ENDED TEXT BOX PROVIDED] 


\section{Appendix B: The Experimental Design}

To maximize the statistical power of a manipulation, we want it to be applied in half the cases and to be orthogonal to the other manipulations. Independently randomizing each manipulation with probability one half will, in expectation, achieve these goals. However, due to sampling variation, randomization will not exactly achieve this goal. Instead, we created an experimental design in which manipulations are exactly applied in half the cases, and in which each manipulation is exactly orthogonal to each other manipulation. Observations were randomly (and without replacement) assigned to one of the combinations of manipulations in the design. While the design file achieves exact orthogonalization, the manipulations in our sample are not exactly orthogonal because some of the respondents who "used up" a manipulation combination from the design file dropped out of our sample because they said that they did not hear the audio during the presentation or because they did not complete the survey.

With 12 manipulations, there are $2^{12}=4084$ possible manipulation combinations, and one would need as many observations to ensure that each manipulation is exactly orthogonal to all possible higher-order interactions of the other 11 manipulations. It seems, however, unlikely that giving is significantly affected by higher-order interactions. We therefore use a fractional factorial design, in which all manipulations are applied in exactly half the cases and each manipulation is orthogonal to all other manipulations as well as to all possible second-order interactions of the other manipulations.

Because of our interest in the effects of race on giving, we wanted to make sure that the picture manipulations are orthogonal to all the other manipulations as well as any higher order interaction of the other manipulations. We achieved this for the main instrument by creating 8 arms based on the 2 picture manipulations (picture race condition and the blur/blue condition) and the race of the respondent. Within each arm, we give the same 32 combinations of the remaining 10 manipulations (9 audio manipulations and the city). This ensures that the picture manipulations and the respondent race are exactly orthogonal to each other, the 10 other manipulations and any higher-order interaction of any of the manipulations. These 32 combinations are given by the $2^{10-5}$ IV fractional factorial design, which means that that each of these 10 manipulations are orthogonal to each other and to any second-order interaction of these 10 manipulations. These same 32 combinations are also given to the $2 \mathrm{arms}$ in the race-salient and in the full-stakes versions of the instrument (recall that these instruments do not have the blue condition).

Since the sample size is larger for the non-black respondents of the main instrument, we gave the 32 manipulations (from the $2^{10-5}$ IV design) three times and, in addition, gave them 128 combinations for the 10 non-picture manipulations from a more powerful fractional factorial design. These 128 combinations come from the $2^{10-3} \mathrm{v}$ fractional factorial design, which means that each of these 10 manipulations are orthogonal to each other, and to any second- and thirdorder interaction of these 10 manipulations. In addition, any second-order interaction of these 10 picture manipulations is orthogonal to any other second-order interaction. The design file for the non-black respondents of the main instrument thus consisted of 4 arms $\times(3 \times 32$ combination from the $2_{\text {IV }}^{10-5}$ design +128 combinations from the $2^{10-3} \mathrm{~V}$ design $)=896$ manipulation combinations. 


\section{Appendix C: Effects of Experimental Manipulations on Perceptions}

In this appendix, we examine the effect of the manipulations on respondents' perceptions of Habitat for Humanity recipients. Appendix Table A.4 presents regressions estimating the effect of the picture manipulations, the audio manipulations, and demographic controls on 1) the perceived percentage of Habitat for Humanity recipients that are black, 2) the perceived percentage that are white, and 3) the perceived percentage that are black minus the perceived percentage that are white.

Panel A shows these effects in the whole sample. The black race manipulation increases the perceived fraction black by 7.8 percentage points, decreases the perceived fraction white by 8.6 percentage points, and increases the difference between the perceived fraction black and perceived fraction white by 16.3 percentage points. All of these effects are significant at the onepercent level. The coefficient on Blurred shows by how much the perceived fraction black changes when respondents see the blurred rather than the blued version of white pictures. These estimates are significant with the expected signs. Finally, the estimate on Black pictures shows the effect of seeing blued black rather than blued white pictures. These estimates are all insignificant, which means that respondents could not infer much about racial composition from the picture backgrounds. The remaining rows show the effects of the audio manipulations. Black respondents are less likely to be Republican. Thus, if respondents are Bayesian, one would expect the audio manipulation that increases the perceived fraction of Republicans in a city to lower the perceived fraction black. This is indeed the case. Similarly, when the audio manipulation suggests the city is relatively economically advantaged, the perceived fraction black decreases. Both of these manipulations have statistically significant effects on all three measures of perceptions about racial composition. The remaining treatment effects are less robust but, by and large, move the perceived racial composition in a fashion that is consistent with Bayesian updating.

Panel B presents the estimated effects of the race manipulation for white and black respondents separately. The effects are roughly twice as large for black respondents. All of these effects are significant at the one- or five-percent level. Panel C shows the effect of the picture manipulation separately for photos of Slidell and of Biloxi. These tables show that there are significant changes in race perceptions in both cities, but the changes are larger and more significant in Slidell.

Panel D shows the effects separately for whites who identify with their ethnic group and whites who do not. The race treatment effect on racial perceptions is small and insignificant for those who are ethnically close and large and highly significant for those who are not. Since those who are ethnically close bias their giving against blacks and those who are not ethnically close bias their giving in favor of blacks, this result suggests that people report perceptions that make their behavior appear more socially acceptable. That is, the ethnically close whites discriminate against blacks but do not admit to seeing more blacks in the black treatment condition.

Appendix Table A5 examines how the picture and audio manipulations affect respondents' perceptions of nine other characteristics of the Habitat recipients or the city they live in. With three exceptions, each audio manipulation changes the corresponding perception in the expected direction and is statistically significant at the $5 \%$ level in the whole sample and each sub-sample. For example, saying that the city is relatively economically advantaged raises the perceived median household income of Habitat recipients by about $\$ 6800$ per year. 


\section{References}

Alesina, Alberto; Baqir, Reza and Easterly, William. 1999. "Public Goods and Ethnic Divisions." Quarterly Journal of Economics. 114(4): pp. 1243-84.

Alesina, Alberto; Baqir, Reza and Hoxby, Caroline. 2004. "Political Jurisdictions in Heterogeneous Communities." Journal of Political Economy. 112(2): pp. 348-96.

Alesina, Alberto; Glaeser, Edward and Sacerdote, Bruce. 2001. "Why Doesn't the United States Have a European-Style Welfare State?" Brookings Papers on Economic Activity. 0(2): pp. 187-278.

Alesina, Alberto and La Ferrara, Eliana. 2000. "Participation in Heterogeneous Communities." Quarterly Journal of Economics. 115(3): pp. 847-904. . 2002. "Who Trusts Others?" Journal of Public Economics. 85(2): pp. 207-34. Altonji, Joseph G. and Blank, Rebecca. 1999. "Race and Gender in the Labor Market." In Handbook of Labor Economics, Vol. 3, ed. O. Ashenfelter and D. Card, 3144-259. Elsevier Science B.V.

Antonovics, Kate; Arcidiacono, Peter and Walsh, Randall. 2005. "Games and Discrimination: Lessons from the Weakest Link." Journal of Human Resources. 40(4): pp. 91847.

Benz, Matthias and Meier, Stephan. 2006. "Do People Behave in Experiments as in the Field? Evidence from Donations." Federal Reserve Bank of Boston Working Paper 06-8.

Bertrand, Marianne and Mullainathan, Sendhil. 2004. "Are Emily and Greg More Employable Than Lakisha and Jamal? A Field Experiment on Labor Market Discrimination." American Economic Review. 94(4): pp. 991-1013.

Boisjoly, Johanne; Duncan, Greg J.; Kremer, Michael; Levy, Dan M. and Eccles, Jacque. 2006. "Empathy or Antipathy? The Impact of Diversity." The American Economic Review. 96(5): pp. 1890-905.

Bouckaert, Jan and Dhaene, Geert. 2004. "Inter-Ethnic Trust and Reciprocity: Results of an Experiment with Small Businessmen." European Journal of Political Economy. 20(4): pp. 86986.

Burns, Justine. 2004. "Inequality Aversion and Group Identity in a Segmented Society." Mimeo. University of Cape Town. . 2006. "Race and Trust in a Segmented Society." Mimeo. University of Cape Town. Camerer, Colin. 2003. Behavioral Game Theory: Experiments in Strategic Interaction. Princeton: Princeton University Press.

Carpenter, Jeffrey; Connolly, Cristina and Myers, Caitlin. 2007. "Altruistic Behavior in a Representative Dictator Experiment." Mimeo. Middlebury College.

Carpenter, Jeffrey; Holmes, Jessica and Matthews, Peter H. Forthcoming. "Charity Auctions: A Field Experiment." Economic Journal.

Corneo, Giacomo and Grüner, Hans Peter. 2002. "Individual Preferences for Political Redistribution." Journal of Public Economics. 83(1): pp. 83-107.

Croson, Rachel and Shang, Jen. 2005. "Field Experiments in Charitable Contribution: The Impact of Social Influence on the Voluntary Provision of Public Goods." Mimeo. University of Texas at Dallas.

Cutler, David M.; Glaeser, Edward L. and Vigdor, Jacob L. 1999. "The Rise and Decline of the American Ghetto." Journal of Political Economy. 107(3): pp. 455-506. 
DiPasquale, Denise and Glaeser, Edward. 1998. "The L.A. Riots and the Economics of Urban Unrest." Journal of Urban Economics. 43(1): pp. 52-78.

Dixon, Jeffrey C. 2006. "The Ties That Bind and Those That Don't: Toward Reconciling Group Threat and Contact Theories of Prejudice." Social Forces. 84(4): pp. 2179-204.

Eckel, Catherine and Grossman, Philip. 1996. "Altruism in Anonymous Dictator Games." Games and Economic Behavior. 16(2): pp. 181-91. . 2006. "Subsidizing Charitable Contributions in the Field: Evidence from a Non-Secular Charity." Mimeo. University of Texas at Dallas. . 2005. "Subsidizing Charitable Contributions: A Field Test Comparing Matching and Rebate Subsidies." Mimeo. University of Texas at Dallas.

Eckel, Catherine and Wilson, Rick. 2003. "Conditional Trust: Sex, Race and Facial Expressions in a Trust Game." Mimeo. University of Texas at Dallas.

Falk, Armin. Forthcoming. "Gift-Exchange in the Field." Econometrica.

Fehr, Ernst and Schmidt, Klaus. 2003. "Theories of Fairness and Reciprocity - Evidence and Economic Applications." In Advances in Economics and Econometrics, Eighth World Congress of the Econometric Society. Vol. 1, ed. M. Dewatripont, L. Hansen and S. Turnovsky, 208-57. Cambridge: Cambridge University Press.

Fershtman, Chaim and Gneezy, Uri. 2001. "Discrimination in a Segmented Society: An Experimental Approach." Quarterly Journal of Economics. 116(1): pp. 351-77.

Fong, Christina M. Forthcoming. "Evidence from an Experiment on Charity to Welfare Recipients: Reciprocity, Altruism and the Empathic Responsiveness Hypothesis." Economic Journal.

. 2001. "Social Preferences, Self-Interest, and the Demand for Redistribution." Journal of Public Economics. 82(2): pp. 225-46.

Fong, Christina M.; Bowles, Samuel and Gintis, Herbert. 2006. "Strong Reciprocity and the Welfare State." In Handbook on the Economics of Giving, Altruism and Reciprocity, Volume 2, ed. S.-C. Kolm and J. M. Ythier, 1440-64. Amsterdam: Elsevier.

Frey, Bruno S. and Meier, Stephan. 2004. "Social Comparisons and Pro-Social Behavior: Testing 'Conditional Cooperation' in a Field Experiment." American Economic Review. 94(5): pp. 1717-22.

Gilens, Martin. 1999. Why Americans Hate Welfare. Chicago: University of Chicago Press. Glaeser, Edward; Laibson, David; Scheinkman, José and Soutter, Christine. 2000. "Measuring Trust." Quarterly Journal of Economics. 115(3): pp. 811-46.

Haile, Daniel; Sadrieh, Abdolkarim and Verbon, Harrie A.A. 2006. "Cross-Racial Envy and Underinvestment in South Africa." Mimeo. Tilburg University.

Harris-Lacewell, Melissa; Imai, Kosuke and Yamamoto, Teppei. 2007. "Racial Gaps in the Responses to Hurricane Katrina: An Experimental Study." Mimeo. Princeton University. Hopkins, Daniel J. 2007. "Politicized Change: How Local Reactions to the Post-Katrina Migration Were Shaped by the Media." Mimeo. Harvard University.

Hungerman, Daniel. 2006. "Race and Charitable Church Activity." Mimeo. University of Notre Dame.

Iyengar, Shanto and Morin, Richard. 2006. "Natural Disasters in Black and White: How Racial Cues Influenced Public Response to Hurricane Katrina." Washingtonpost.com. Karlan, Dean and List, John A. Forthcoming. "Does Price Matter in Charitable Giving? Evidence from a Large-Scale Natural Field Experiment." American Economic Review. 
Kolm, Serge-Christophe and Ythier, Jean Mercier, eds. 2006. Handbook on the Economics of Giving, Altruism and Reciprocity. Amsterdam: Elsevier.

Konow, James. 2003. "Which Is the Fairest One of All? A Positive Analysis of Justice Theories." Journal of Economic Literature. 41(4): pp. 1188-239.

Landry, Craig; Lange, Andreas; List, John A.; Price, Michael K. and Rupp, Nicholas G. 2005. "Toward an Understanding of the Economics of Charity: Evidence from a Field Experiment." NBER Working Paper \#11611.

Lee, Woojin and Roemer, John E. 2006. "Racism and Redistribution in the United States: A Solution to the Problem of American Exceptionalism." Journal of Public Economics. 90(6-7): pp. 1027-52.

Levitt, Steven. 2004. "Testing Theories of Discrimination: Evidence from Weakest Link." The Journal of Law and Economics. 47: pp. 431-52.

Levitt, Steven D. and List, John A. 2007. "What Do Laboratory Experiments Measuring Social Preferences Reveal About the Real World?" Journal of Economic Perspectives. 21(2): pp.153174.

List, John A. 2004. "The Nature and Extent of Discrimination in the Marketplace: Evidence from the Field." Quarterly Journal of Economics. 119(1): pp. 49-89.

List, John A. 2006. "Friend or Foe? A Natural Experiment of the Prisoner's Dilemma." Review of Economics and Statistics. 88(3): pp. 463-71.

Luttmer, Erzo F.P. 2001. "Group Loyalty and the Taste for Redistribution." Journal of Political Economy. 109(3): pp. 500-28.

Munnell, Alicia H.; Tootell, Geoffrey M.B.; Browne, Lynn E. and McEneaney, James. 1996. "Mortgage Lending in Boston: Interpreting HMDA Data." American Economic Review. 86(1): pp. 25-53.

Nordhaus, William D. 2006. "The Economics of Hurricanes in the United States." NBER Working Paper \#12813.

Pager, Devah and Freese, Jeremy. 2006. "Who Deserves a Helping Hand?: Attitudes About Government Assistance for the Unemployed by Race, Incarceration Status, and Worker History." Mimeo. Northwestern University.

Pager, Devah; Western, Bruce and Bonikowski, Bart. 2006. "Discrimination in Low-Wage Labor Markets." Mimeo. Northwestern University.

Small, Deborah A and Loewenstein, George. 2003. "Helping a Victim or Helping the Victim: Altruism and Identifiability." Journal of Risk and Uncertainty. 26(1): pp. 5-16. Sobel, Joel. 2005. "Interdependent Preferences and Reciprocity." Journal of Economic Literature. 43(2): pp. 392-436.

Viscusi, W. Kip and Zeckhauser, Richard J. "National Survey Evidence on Disasters and Relief: Risk Beliefs, Self-Interest, and Compassion." Journal of Risk and Uncertainty, 2006, 33(1-2), pp. 13-36. 


\section{Figure 1. Difference-in-Differences Design}

(A)

Black picture \& Blur

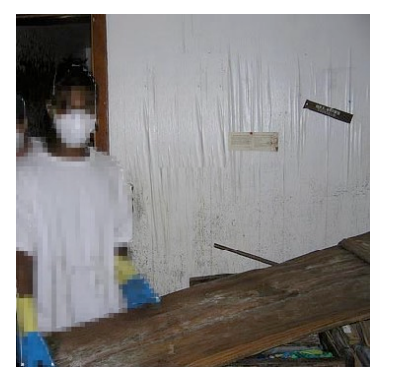

(B)

White picture \& Blur

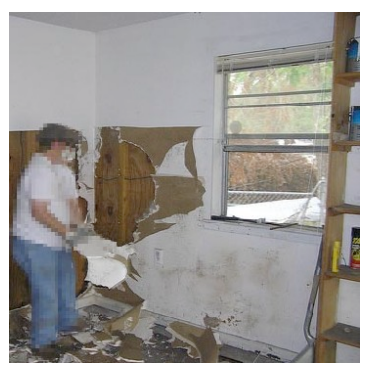

A-B $=$ Effect of race and background
(C)

Black picture \& Blue

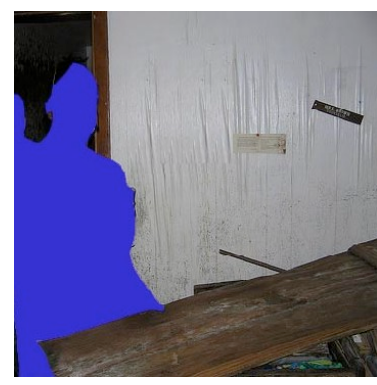

(D)

White picture \& Blue

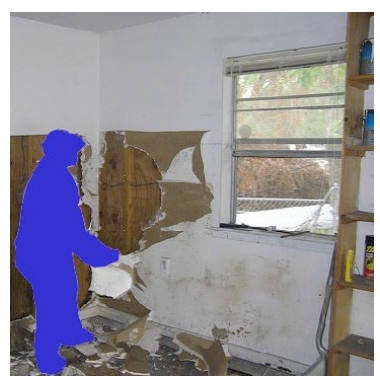

$=\quad \mathrm{B}-\mathrm{D}=$ Effect of white race

$\mathrm{C}-\mathrm{D}=$ Effect of background difference only (relative to unknown race)

A-B-C+D = Effect of

$=\begin{aligned} & \text { A-C }=\text { Effect of black race } \\ & \text { (relative to unknown race) }\end{aligned}$

black race relative to white race 
Table 1: Mean Giving to Habitat for Humanity to Help Katrina Victims (Out of \$100)

\begin{tabular}{|c|c|c|c|}
\hline & $\begin{array}{c}\text { Pictures reveal race } \\
\text { (blurred version) }\end{array}$ & $\begin{array}{c}\text { Pictures hide race } \\
\text { (blued version) }\end{array}$ & Difference \\
\hline Pictures of black victims & $66.3(2.2)$ & $65.6(2.2)$ & $0.7(3.1)$ \\
\hline $\mathrm{N}$ & 280 & 273 & \\
\hline Pictures of white victims & $64.7(2.2)$ & $63.9(2.2)$ & $0.8(3.1)$ \\
\hline $\mathrm{N}$ & 280 & 268 & \\
\hline Difference & $1.6(3.1)$ & $1.7(3.1)$ & $-0.1(4.4)$ \\
\hline
\end{tabular}


Table 2: Giving to Habitat for Humanity to Help Katrina Victims (Out of \$100)

\begin{tabular}{|c|c|c|c|c|c|c|}
\hline & \multicolumn{2}{|c|}{ All respondents } & \multicolumn{2}{|c|}{ White respondents } & \multicolumn{2}{|c|}{ Black respondents } \\
\hline & Coefficient & (S.E.) & Coefficient & (S.E.) & Coefficient & (S.E.) \\
\hline Black pictures $\times$ Blurred & -2.2 & $(3.8)$ & -4.1 & $(4.7)$ & 5.6 & $(8.5)$ \\
\hline Blurred pictures & $4.6^{*}$ & $(2.8)$ & 5.3 & $(3.5)$ & -0.2 & $(5.8)$ \\
\hline Black pictures & 0.9 & $(3.0)$ & 1.7 & (3.7) & -7.3 & $(5.8)$ \\
\hline \multicolumn{7}{|l|}{ Audio Manipulations: } \\
\hline Republican & 0.6 & $(1.9)$ & -0.7 & $(2.3)$ & 1.4 & $(4.2)$ \\
\hline Economically advantaged & $-4.2^{* *}$ & $(1.9)$ & $-6.1^{* * *}$ & (2.3) & 1.9 & $(4.1)$ \\
\hline Received government assistance & -1.2 & $(1.9)$ & -1.1 & (2.3) & -4.9 & $(4.0)$ \\
\hline Prepares for hurricanes & 1.1 & $(1.9)$ & 3.1 & (2.3) & -1.0 & $(4.4)$ \\
\hline Church attendance & -2.6 & $(1.9)$ & -0.2 & (2.3) & 3.2 & $(4.3)$ \\
\hline Crime & -0.2 & $(1.9)$ & 0.5 & (2.3) & -1.4 & $(4.1)$ \\
\hline Willing to help others & 2.0 & $(1.9)$ & 0.6 & $(2.3)$ & $10.0^{* *}$ & $(4.1)$ \\
\hline Sweat equity & -0.7 & $(1.9)$ & -0.2 & (2.3) & 1.5 & $(4.2)$ \\
\hline Mention of looting & -1.5 & $(1.9)$ & -3.1 & (2.3) & -0.1 & $(4.1)$ \\
\hline \multicolumn{7}{|l|}{ Other Manipulations: } \\
\hline Slidell & 3.3 & $(2.6)$ & $5.4^{*}$ & (3.2) & 0.1 & $(6.5)$ \\
\hline Full-stakes & $-14.8^{* * *}$ & $(3.6)$ & $-16.4^{* * *}$ & $(4.1)$ & & \\
\hline Race-salient & -3.1 & $(3.4)$ & -3.0 & (3.8) & & \\
\hline \multicolumn{7}{|l|}{ Respondent Demographic Controls: } \\
\hline Age & $1.6^{* * *}$ & $(0.4)$ & $1.6^{\star * *}$ & $(0.4)$ & $1.3^{*}$ & $(0.8)$ \\
\hline $\mathrm{Age}^{2} / 100$ & $-1.2^{* * *}$ & $(0.4)$ & $-1.3^{* * *}$ & $(0.5)$ & -0.5 & $(0.8)$ \\
\hline Non-Hispanic black & $-10.6^{* * *}$ & $(2.6)$ & & & & \\
\hline Other race/ethnicity & -0.6 & $(2.7)$ & & & & \\
\hline High school dropout & -1.1 & (3.3) & -1.9 & (4.3) & 5.2 & $(6.3)$ \\
\hline Some college & -0.1 & $(2.5)$ & -4.6 & (3.1) & $17.5^{* * *}$ & $(5.1)$ \\
\hline College or more & 3.1 & $(2.7)$ & 0.6 & $(3.2)$ & $17.6^{\star \star *}$ & $(6.6)$ \\
\hline Log household income & $3.6^{* * *}$ & $(1.4)$ & 2.5 & (1.7) & 4.2 & $(2.7)$ \\
\hline Dual income family & $-5.1^{* *}$ & $(2.1)$ & $-4.8^{*}$ & (2.5) & 3.2 & $(4.6)$ \\
\hline Married & -1.9 & $(2.8)$ & 0.9 & (3.5) & -6.6 & $(5.8)$ \\
\hline Male & 0.8 & $(2.6)$ & 1.1 & (3.0) & 0.8 & $(6.8)$ \\
\hline Single male & $-7.2^{*}$ & (3.9) & -5.2 & $(4.9)$ & -8.1 & $(8.9)$ \\
\hline South & $-3.6^{*}$ & $(2.0)$ & -3.2 & $(2.4)$ & -0.7 & $(4.1)$ \\
\hline Employed & 4.1 & $(2.9)$ & 3.3 & $(3.5)$ & 6.4 & $(6.6)$ \\
\hline Disabled & $7.8^{*}$ & $(4.6)$ & 6.6 & $(6.1)$ & 7.3 & $(8.3)$ \\
\hline Retired & 0.8 & $(4.0)$ & -0.2 & $(4.8)$ & 3.4 & $(9.4)$ \\
\hline Any charity giving in 2005 & $11.0^{* \star *}$ & $(3.2)$ & $17.0^{\star * *}$ & $(4.0)$ & -0.9 & $(6.3)$ \\
\hline Any prior Katrina relief giving & $4.4^{*}$ & $(2.4)$ & 3.8 & $(2.9)$ & -2.5 & $(5.2)$ \\
\hline Log giving to charity in 2005 & $2.7^{* * *}$ & $(0.9)$ & $2.6^{\star *}$ & $(1.0)$ & $4.3^{* *}$ & $(2.1)$ \\
\hline Log prior giving to Katrina relief & -0.4 & $(1.2)$ & 0.0 & $(1.4)$ & -4.0 & $(2.9)$ \\
\hline $\mathrm{R}^{2}$ & \multicolumn{2}{|c|}{0.177} & \multicolumn{2}{|c|}{0.167} & \multicolumn{2}{|c|}{0.263} \\
\hline $\mathrm{N}$ & \multicolumn{2}{|c|}{1343} & \multicolumn{2}{|c|}{915} & \multicolumn{2}{|c|}{247} \\
\hline
\end{tabular}

Note: Robust standard errors are in parentheses. Significance levels: ${ }^{*} 10$ percent; ${ }^{* *} 5$ percent; ${ }^{* * *} 1$ percent. The outcome variable is the dollar amount that the respondent chose to give to Katrina victims via Habitat for Humanity in the city in question. Weighted to adjust for oversampling of African Americans. The Log giving variables are demeaned. Omitted categories are "Non-Hispanic white", "High school degree" and "Not working for another reason." 


\begin{tabular}{|c|c|c|c|c|c|c|c|}
\hline & & \multicolumn{2}{|c|}{ All respondents } & \multicolumn{2}{|c|}{ White respondents } & \multicolumn{2}{|c|}{ Black respondents } \\
\hline & & $\begin{array}{c}\text { Black } \\
\text { pictures } \\
\text { x Blurred }\end{array}$ & $\begin{array}{c}\text { Audio } \\
\text { manipulation: } \\
\text { Economically } \\
\text { advantaged }\end{array}$ & $\begin{array}{c}\text { Black } \\
\text { pictures } \\
\text { x Blurred }\end{array}$ & $\begin{array}{c}\text { Audio } \\
\text { manipulation: } \\
\text { Economically } \\
\text { advantaged }\end{array}$ & $\begin{array}{c}\text { Black } \\
\text { pictures } \\
\text { x Blurred }\end{array}$ & $\begin{array}{c}\text { Audio } \\
\text { manipulation: } \\
\text { Economically } \\
\text { advantaged }\end{array}$ \\
\hline & & $\begin{array}{l}\text { Coeff. } \\
\text { (S.E.) }\end{array}$ & $\begin{array}{l}\text { Coeff. } \\
\text { (S.E.) }\end{array}$ & $\begin{array}{l}\text { Coeff. } \\
\text { (S.E.) }\end{array}$ & $\begin{array}{l}\text { Coeff. } \\
\text { (S.E.) }\end{array}$ & $\begin{array}{l}\text { Coeff. } \\
\text { (S.E.) }\end{array}$ & $\begin{array}{l}\text { Coeff. } \\
\text { (S.E.) }\end{array}$ \\
\hline (1) & Baseline & $\begin{array}{l}-2.2 \\
(3.8)\end{array}$ & $\begin{array}{l}-4.2^{* *} \\
(1.9)\end{array}$ & $\begin{array}{l}-4.1 \\
(4.7)\end{array}$ & $\begin{array}{l}-6.1^{* * *} \\
(2.3)\end{array}$ & $\begin{array}{c}5.6 \\
(8.5)\end{array}$ & $\begin{array}{c}1.9 \\
(4.1)\end{array}$ \\
\hline (2) & $\begin{array}{l}\text { Excluding full-stakes } \\
\text { and race-salient }\end{array}$ & $\begin{array}{l}-1.4 \\
(4.2)\end{array}$ & $\begin{array}{l}-4.5^{* *} \\
(2.1)\end{array}$ & $\begin{array}{l}-3.7 \\
(5.1)\end{array}$ & $\begin{array}{l}-5.9^{* *} \\
(2.6)\end{array}$ & $\begin{array}{c}5.5 \\
(8.5)\end{array}$ & $\begin{array}{c}1.9 \\
(4.1)\end{array}$ \\
\hline (3) & Slidell sample & $\begin{array}{l}-0.4 \\
(5.3)\end{array}$ & $\begin{array}{l}-6.6^{* *} \\
(2.7)\end{array}$ & $\begin{array}{c}1.6 \\
(6.6)\end{array}$ & $\begin{array}{l}-6.6^{* *} \\
(3.2)\end{array}$ & $\begin{array}{c}-5.1 \\
(11.9)\end{array}$ & $\begin{array}{l}-7.9 \\
(5.8)\end{array}$ \\
\hline (4) & Biloxi sample & $\begin{array}{l}-3.8 \\
(5.6)\end{array}$ & $\begin{array}{l}-1.2 \\
(2.7)\end{array}$ & $\begin{array}{l}-8.6 \\
(6.6)\end{array}$ & $\begin{array}{l}-4.6 \\
(3.3)\end{array}$ & $\begin{array}{c}18.1 \\
(11.5)\end{array}$ & $\begin{aligned} 12.1^{* *} \\
(6.0)\end{aligned}$ \\
\hline (5) & $\begin{array}{l}\text { No demographic } \\
\text { controls }\end{array}$ & $\begin{array}{l}-1.7 \\
(4.1)\end{array}$ & $\begin{array}{l}-4.3^{\star *} \\
(2.0)\end{array}$ & $\begin{array}{l}-3.0 \\
(4.9)\end{array}$ & $\begin{array}{l}-6.2^{* *} \\
(2.4)\end{array}$ & $\begin{array}{c}7.5 \\
(8.6)\end{array}$ & $\begin{array}{l}-1.7 \\
(4.4)\end{array}$ \\
\hline (6) & Extra controls & $\begin{array}{l}-3.0 \\
(3.7)\end{array}$ & $\begin{array}{l}-3.8^{* *} \\
(1.8)\end{array}$ & $\begin{array}{l}-4.8 \\
(4.5)\end{array}$ & $\begin{array}{l}-5.5^{\star *} \\
(2.3)\end{array}$ & $\begin{array}{c}5.3 \\
(8.5)\end{array}$ & $\begin{array}{c}0.8 \\
(4.1)\end{array}$ \\
\hline (7) & Censored regression & $\begin{array}{l}-3.3 \\
(7.6)\end{array}$ & $\begin{array}{l}-7.8^{* *} \\
(3.7)\end{array}$ & $\begin{array}{c}-5.3 \\
(10.5)\end{array}$ & $\begin{array}{r}-13.1^{* *} \\
(5.1)\end{array}$ & $\begin{array}{c}5.2 \\
(11.5)\end{array}$ & $\begin{array}{c}2.6 \\
(5.7)\end{array}$ \\
\hline (8) & Blurred pictures only & $\begin{array}{l}-1.4 \\
(2.4)\end{array}$ & $\begin{array}{l}-5.2^{* *} \\
(2.4)\end{array}$ & $\begin{array}{l}-2.4 \\
(2.9)\end{array}$ & $\begin{array}{l}-6.2^{* *} \\
(2.9)\end{array}$ & $\begin{array}{l}-2.7 \\
(6.0)\end{array}$ & $\begin{array}{l}-4.0 \\
(6.0)\end{array}$ \\
\hline
\end{tabular}

Note: Robust standard errors in parentheses. Significance levels: * 10 percent: ** 5 percent: $* * * 1$ percent. Each pair of coefficients, under a sample heading, is from a single regression run using the specification in the row. Control variables are the same as in Table 2. The outcome variable is the dollar amount that the respondent chose to give to Katrina victims via Habitat for Humanity in the city in question. The extra controls include subjective assessments of the effectiveness of Habitat for Humanity, how much the respondent values helping others, and how much the respondent cares about money. Weighted to adjust for oversampling of African Americans. 
Table 4: Racial Group Loyalty, Race Salience, and Full Stakes

\begin{tabular}{|c|c|c|c|c|}
\hline & \multicolumn{2}{|c|}{$\underline{\text { Testing for racial group loyalty }}$} & \multicolumn{2}{|c|}{ Alternative survey versions } \\
\hline & $\begin{array}{l}\text { DDD } \\
\text { Coeff. } \\
\text { (S.E.) } \\
\end{array}$ & $\begin{array}{l}\text { DD } \\
\text { Coeff. } \\
\text { (S.E.) } \\
\end{array}$ & $\begin{array}{l}\text { Race-salient } \\
\text { Coeff. } \\
\text { (S.E.) }\end{array}$ & $\begin{array}{c}\text { Full-stakes } \\
\text { Coeff. } \\
\text { (S.E.) } \\
\end{array}$ \\
\hline Black pictures $\times$ Black respondent $\times$ Blurred & $\begin{array}{l}9.6 \\
(9.6)\end{array}$ & $\begin{array}{c}0.0 \\
(6.6)\end{array}$ & & \\
\hline Black pictures $\times$ Black respondent & $\begin{array}{l}-8.7 \\
(7.0)\end{array}$ & & & \\
\hline Black respondent $\times$ Blurred & $\begin{array}{l}-5.6 \\
(6.8)\end{array}$ & & & \\
\hline Black pictures $\times$ Race salient $\times$ Blurred & & & $\begin{array}{l}-6.5 \\
(7.6)\end{array}$ & \\
\hline Black pictures $\times$ Full stakes $\times$ Blurred & & & & $\begin{array}{l}4.4 \\
(8.3)\end{array}$ \\
\hline Black pictures $\times$ Blurred & $\begin{array}{l}-3.8 \\
(4.7)\end{array}$ & $\begin{array}{l}-2.1 \\
(2.9)\end{array}$ & $\begin{array}{l}-3.9 \\
(5.1)\end{array}$ & $\begin{array}{l}-3.7 \\
(5.1)\end{array}$ \\
\hline Black pictures & $\begin{array}{l}1.8 \\
(3.7)\end{array}$ & & $\begin{array}{l}1.4 \\
(3.7)\end{array}$ & $\begin{array}{l}1.6 \\
(3.7)\end{array}$ \\
\hline Blurred & $\begin{array}{l}5.1 \\
(3.5)\end{array}$ & & $\begin{array}{l}5.2 \\
(3.6)\end{array}$ & $\begin{array}{l}4.9 \\
(3.6)\end{array}$ \\
\hline Race salient & & & $\begin{array}{l}0.4 \\
(5.1)\end{array}$ & \\
\hline Full stakes & & & & $\begin{array}{l}-18.7^{\star \star *} \\
(5.9)\end{array}$ \\
\hline Demographic and manipulation controls & Yes & Yes & Yes & Yes \\
\hline $\begin{array}{l}\mathrm{R}^{2} \\
\mathrm{~N}\end{array}$ & $\begin{array}{l}0.170 \\
1162\end{array}$ & $\begin{array}{c}0.206 \\
684\end{array}$ & $\begin{array}{c}0.165 \\
814\end{array}$ & $\begin{array}{c}0.155 \\
818\end{array}$ \\
\hline Sample & $\begin{array}{l}\text { White resp. } \\
\text { Black resp. }\end{array}$ & $\begin{array}{l}\text { White resp. } \\
\text { Black resp. } \\
\text { Blurred only }\end{array}$ & $\begin{array}{l}\text { White resp. } \\
\text { only }\end{array}$ & $\begin{array}{l}\text { White resp. } \\
\text { only }\end{array}$ \\
\hline
\end{tabular}

Note: Robust standard errors in parentheses. Significance levels: ${ }^{*} 10$ percent; ${ }^{* \star} 5$ percent; ${ }^{\star * *} 1$ percent. The outcome variable is the dollar amount that the respondent chose to give to Katrina victims via Habitat for Humanity in the city in question. Weighted to adjust for oversampling of African Americans. 


\begin{tabular}{|c|c|c|c|c|c|c|}
\hline \multirow[b]{2}{*}{ Specification } & \multicolumn{2}{|c|}{$\begin{array}{c}\text { Black pictures } \times \\
\text { Blurred }\end{array}$} & \multicolumn{2}{|c|}{$\begin{array}{l}\text { Audio manipulation: } \\
\text { Econ. advantaged }\end{array}$} & \multirow[b]{2}{*}{ Adj. $R^{2}$} & \multirow[b]{2}{*}{$\mathrm{N}$} \\
\hline & Coeff. & $\begin{array}{c}\text { S.E. } \\
\text { (p-value) }\end{array}$ & Coeff. & $\begin{array}{c}\text { S.E. } \\
\text { (p-value) }\end{array}$ & & \\
\hline \multicolumn{7}{|l|}{ Panel A: By measures of race relations } \\
\hline Very close/Close & $-16.7^{* *}$ & 6.9 & -4.7 & 3.1 & & (429) \\
\hline Not very close/Not close at all & $13.2^{*}$ & 7.8 & $-7.6^{* *}$ & 3.2 & & $(320)$ \\
\hline P-value on test of equal coefficients & & $(0.005)$ & & $(0.436)$ & & \\
\hline (2) Blacks have... & & & & & 0.174 & 908 \\
\hline The same or more economic opportunities & -3.6 & 5.9 & $-6.8^{* * *}$ & 2.6 & & $(628)$ \\
\hline Fewer economic opportunities & -6.9 & 7.9 & -4.3 & 3.2 & & $(280)$ \\
\hline P-value on test of equal coefficients & & $(0.741)$ & & $(0.470)$ & & \\
\hline \multicolumn{5}{|c|}{ (3) Social contact with blacks minus contact with whites } & 0.167 & 903 \\
\hline Equal or more social contact with blacks & $-17.9^{* *}$ & 8.2 & -3.8 & 3.2 & & $(344)$ \\
\hline More contact with whites than blacks & 2.7 & 5.8 & $-7.0^{* * *}$ & 2.6 & & (559) \\
\hline P-value on test of equal coefficients & & $(0.041)$ & & $(0.351)$ & & \\
\hline \multicolumn{7}{|l|}{ Panel B: By demographic characteristics } \\
\hline (4) Lives in South & & & & & 0.169 & 915 \\
\hline Lives in South & -11.3 & 8.0 & -4.6 & 3.3 & & $(312)$ \\
\hline Does not live in South & -0.4 & 5.8 & $-6.7^{* * *}$ & 2.6 & & $(603)$ \\
\hline P-value on test of equal coefficients & & $(0.274)$ & & $(0.565)$ & & \\
\hline (5) Age & & & & & 0.172 & 915 \\
\hline Younger than 50 & -3.4 & 6.9 & -3.1 & 2.9 & & $(457)$ \\
\hline 50 or older & -5.9 & 6.4 & $-8.9^{* * \star}$ & 2.8 & & $(458)$ \\
\hline P-value on test of equal coefficients & & $(0.788)$ & & $(0.084)$ & & \\
\hline (6) Education & & & & & 0.172 & 915 \\
\hline High school or less & -4.4 & 7.3 & $-8.0^{* * *}$ & 3.0 & & $(406)$ \\
\hline Some college or more & -5.2 & 6.1 & -4.3 & 2.7 & & $(509)$ \\
\hline P-value on test of equal coefficients & & $(0.929)$ & & $(0.264)$ & & \\
\hline (7) Party affiliation & & & & & 0.165 & 906 \\
\hline Republican & -2.8 & 6.7 & $-7.4^{* *}$ & 3.0 & & $(447)$ \\
\hline Democrat/Independent/Other & -4.4 & 6.6 & $-5.3^{*}$ & 2.7 & & (459) \\
\hline P-value on test of equal coefficients & & $(0.863)$ & & $(0.528)$ & & \\
\hline
\end{tabular}

Note: Significance levels: ${ }^{*} 10$ percent, ${ }^{* *} 5$ percent, ${ }^{* * *} 1$ percent. The outcome variable is the dollar amount that the respondent chose to give to Katrina victims via Habitat for Humanity in the city in question. Each specification is a single OLS regression in which "Black pictures $x$ Blurred" and "Audio manipulation: Economically advantaged" are interacted with the dummy variables mentioned in the row. The regression also controls for the direct effect of these dummy variables as well as the the controls listed in Table 2. The sample is restricted to nonHispanic white respondents. 


Black pictures economically deservingness

x Blurred advantaged manipulations

Coeff. (S.E.) Coeff. (S.E.) Coeff. (S.E.) Adj. $\mathrm{R}^{2} \quad \mathrm{~N}$

(1) Baseline (Giving to Habitat to help Katrina victims in city, $\$$ out of $\$ 100$ )

$\begin{array}{lcccccccc}\text { All respondents } & -2.2 & (3.8) & -4.2^{* *} & (1.9) & 0.7 & (0.9) & 0.176 & 1343 \\ \text { White respondents } & -4.0 & (4.7) & -6.1^{* * *} & (2.3) & 0.8 & (1.2) & 0.165 & 915 \\ \text { Black respondents } & 7.1 & (8.5) & 1.9 & (4.1) & 2.9 & (2.2) & 0.249 & 247\end{array}$

(2) Hypothetical giving to Habitat to help Katrina victims in city (\$)

$\begin{array}{lcccccccc}\text { All respondents } & 0.5 & (3.8) & 1.3 & (2.1) & 0.8 & (1.2) & 0.117 & 1341 \\ \text { White respondents } & -2.3 & (4.0) & 2.0 & (2.5) & 1.4 & (1.1) & 0.116 & 913 \\ \text { Black respondents } & 7.0 & (13.8) & 2.5 & (6.9) & -6.9^{*} & (4.1) & 0.163 & 247\end{array}$

(3) Subjective support for charity spending to help Katrina victims in city (1-7 scale)

$\begin{array}{lllllllll}\text { All respondents } & -0.20 & (0.13) & -0.09 & (0.06) & 0.03 & (0.03) & 0.059 & 1333 \\ \text { White respondents } & -0.22 & (0.16) & -0.11 & (0.07) & 0.03 & (0.04) & 0.066 & 907 \\ \text { Black respondents } & -0.62^{*} & (0.37) & -0.08 & (0.20) & 0.01 & (0.10) & 0.105 & 246\end{array}$

(4) Subjective support for government spending to help Katrina victims in city (1-7 scale)

$\begin{array}{lllllllll}\text { All respondents } & -0.22 & (0.16) & -0.11 & (0.08) & 0.14^{* * *} & (0.04) & 0.091 & 1337 \\ \text { White respondents } & -0.44^{* *} & (0.20) & -0.10 & (0.09) & 0.16^{* * *} & (0.05) & 0.083 & 913 \\ \text { Black respondents } & 0.06 & (0.40) & -0.23 & (0.20) & 0.02 & (0.10) & 0.110 & 245\end{array}$

Note: Robust standard errors in parentheses. Significance levels: *10 percent; ${ }^{* *} 5$ percent; *** 1 percent. Results for all respondents are

weighted to adjust for oversampling of African Americans. Hypothetical giving is topcoded at $\$ 500$, which affected 6 observations. The number of deservingness manipulations is equal to the sum of the dummy variables for the audio manipulations "willing to help others", "sweat equity", and "prepares for hurricanes" minus the dummy for the audio manipulation "crime". 
Table A.1: Comparison of Knowledge Networks and CPS Demographic Means

\begin{tabular}{|c|c|c|c|c|c|c|}
\hline & KN Mean & KN S.D. & CPS Mean & CPS S.D. & $\begin{array}{c}\text { Difference in } \\
\text { Means } \\
\text { (KN-CPS) }\end{array}$ & P-Value \\
\hline Age & 47.9 & 16.3 & 45.7 & 17.4 & 2.2 & 0.00 \\
\hline $\mathrm{Age}^{2} / 100$ & 25.6 & 16.2 & 23.9 & 17.3 & 1.7 & 0.00 \\
\hline Less than high school & 0.128 & 0.33 & 0.154 & 0.36 & -0.026 & 0.01 \\
\hline High school & 0.320 & 0.47 & 0.317 & 0.47 & 0.003 & 0.79 \\
\hline Some college & 0.272 & 0.45 & 0.269 & 0.44 & 0.003 & 0.82 \\
\hline Bachelor's degree or higher & 0.279 & 0.45 & 0.260 & 0.44 & 0.019 & 0.13 \\
\hline Non-Hispanic black & 0.120 & 0.33 & 0.112 & 0.32 & 0.008 & 0.31 \\
\hline Non-Hispanic white & 0.735 & 0.44 & 0.695 & 0.46 & 0.039 & 0.00 \\
\hline Other race/ethnicity & 0.145 & 0.35 & 0.192 & 0.39 & -0.047 & 0.00 \\
\hline Male & 0.463 & 0.50 & 0.483 & 0.50 & -0.020 & 0.15 \\
\hline Log household size & 0.816 & 0.53 & 0.947 & 0.53 & -0.130 & 0.00 \\
\hline Log household income & 10.57 & 0.92 & 10.74 & 0.98 & -0.171 & 0.00 \\
\hline Total household income less than $\$ 20,000$ annually & 0.190 & 0.39 & 0.168 & 0.37 & 0.022 & 0.04 \\
\hline Total household income $\$ 20,000$ to $\$ 40,000$ annually & 0.264 & 0.44 & 0.237 & 0.43 & 0.027 & 0.03 \\
\hline Total household income $\$ 40,000$ to $\$ 75,000$ annually & 0.321 & 0.47 & 0.297 & 0.46 & 0.024 & 0.07 \\
\hline Total household income $\$ 75,000$ to $\$ 100,000$ annually & 0.119 & 0.32 & 0.124 & 0.33 & -0.005 & 0.58 \\
\hline Total household income more than $\$ 100,000$ annually & 0.107 & 0.31 & 0.174 & 0.38 & -0.068 & 0.00 \\
\hline Married & 0.568 & 0.50 & 0.564 & 0.50 & 0.004 & 0.80 \\
\hline Households with children under 18 -- Presence of own children under 18 & 0.264 & 0.44 & 0.299 & 0.46 & -0.035 & 0.00 \\
\hline Married with children & 0.177 & 0.38 & 0.243 & 0.43 & -0.066 & 0.00 \\
\hline Married without children & 0.391 & 0.49 & 0.321 & 0.47 & 0.069 & 0.00 \\
\hline Single, without children & 0.179 & 0.38 & 0.056 & 0.42 & 0.123 & 0.00 \\
\hline Divorced, separated, or widowed; without children & 0.166 & 0.37 & 0.222 & 0.36 & -0.056 & 0.00 \\
\hline Single, divorced, separated, or widowed; with children & 0.199 & 0.40 & 0.157 & 0.23 & -0.070 & 0.00 \\
\hline Lives in the Northeast & 0.187 & 0.39 & 0.187 & 0.39 & 0.000 & 0.98 \\
\hline Lives in the Midwest & 0.232 & 0.42 & 0.223 & 0.42 & 0.008 & 0.48 \\
\hline Lives in the South & 0.375 & 0.48 & 0.362 & 0.48 & 0.013 & 0.34 \\
\hline Lives in the West & 0.207 & 0.41 & 0.228 & 0.42 & -0.021 & 0.07 \\
\hline Lives in a metropolitan area & 0.824 & 0.38 & 0.834 & 0.37 & -0.010 & 0.36 \\
\hline Retired & 0.173 & 0.38 & 0.163 & 0.37 & 0.010 & 0.34 \\
\hline Disabled & 0.078 & 0.27 & 0.049 & 0.22 & 0.029 & 0.00 \\
\hline Unemployed, temporarily laid off, or looking for work & 0.040 & 0.20 & 0.030 & 0.17 & 0.011 & 0.05 \\
\hline Not working for another reason & 0.120 & 0.32 & 0.110 & 0.31 & 0.009 & 0.30 \\
\hline
\end{tabular}

This data was extracted from the June 2006 Current Population Survey; the sample is limited to individuals 18 and older. In cases where the variable definitions in the Knowledge Networks data is 1343. The number of observations for CPS data is 101,073, except for the income variables which have 83,591 observations. 
Table A.2: Definitions of Audio Manipulations and Perception Questions Audio Manipulations Text

0) --nothing mentioned--

1) For example, while New Orleans votes overwhelmingly Democratic,

Republicans have a solid majority in [city].

$\%$ Vote for Bush

Now, we'd like to ask you about Habitat for Humanity recipients in [city] who voted in the 2004 Presidential election. As your best guess, what percentage of these people voted for George W. Bush?

\section{Economically advantaged}

Biloxi:

Income of Habitat recipients

-1) Economically, Biloxi is relatively disadvantaged. Prior to Katrina, its median household income was well below the national average and its poverty rate was 18 percent higher than the rest of the country.

0) --nothing mentioned--

We'd like to know what you think the median household income is for recipients of Habitat for Humanity in [city]. The median (i.e., middle) household income is the income where half of the Habitat households are richer and half are poorer.

Slidell:

0) --nothing mentioned--

1) Economically, Slidell is relatively well-off. Prior to Katrina, its median household income was above the national average and its poverty rate was 5 percent lower than the rest of the country.

\section{Received government assistance prior to Katrina}

0) As a result, many employees stopped receiving their pay-checks.

1) As a result, many recipients of government assistance stopped receiving their benefit checks

\section{Prepares for hurricanes}

0) Partly because many residents underestimated the risk of hurricanes, Katrina did considerable damage.

1) Even though many residents took reasonable precautions against hurricanes, Katrina did considerable damage.

Church attendance
0) Many residents do not attend church on Sunday
1) Many residents attend church on Sunday.

1) Many residents attend church on Sunday.

\section{Crime}

0) This city has mostly law-abiding citizens.

1) This city has been troubled by crime and drug abuse
$\%$ Received government assistance prior to Katrina As your best guess, what percentage of recipients of Habitat for Humanity in [city] received government cash assistance before Katrina hit?

$\%$ Prepared for hurricanes

As your best guess, what percentage of recipients of Habitat for Humanity in [city] prepared as well as one can reasonably expect for Hurricane Katrina?

\section{$\%$ Attend church}

As your best guess, what percentage of recipients of Habitat for Humanity in [city] attend religious services almost every week?

\section{$\%$ With a criminal record}

As your best guess, what percentage of recipients of Habitat for Humanity in [city] have a criminal record?

\section{$\%$ Helping others}

As your best guess, what percentage of adult recipients of Habitat for Humanity in [city] helped fellow hurricane victims when the threat of the Hurricane became clear?
0) When the threat of the Hurricane became clear, many residents became mostly concerned about their own situation and did not help others in need.

1) When the threat of the Hurricane became clear, many residents became concerned about the situation and helped others in need.

\section{Sweat equity}

0) --nothing mentioned--

1) In return, they must invest at least 300 hours of labor - so-called "sweat equity" - into building their own home plus homes for other families.

\section{Mention of looting}

0) --nothing mentioned--

1) In the aftermath of Katrina, however, looting and lawlessness were a concern.
$\%$ Willing to work hard

As your best guess, what percentage of recipients of Habitat for Humanity in [city] are willing to work hard in order to get ahead in life?

No corresponding perception question
No manipulation for windspeed
Windspeed in Town

First, we'd like to know how severe you thought Hurricane Katrina was when it hit [city]. What do you think was the maximum sustained wind speed in [city] when Katrina hit?

(1): 74-95 mph (Category 1 hurricane)

(2): $96-110 \mathrm{mph}$ (Category 2 hurricane)

(3): 111-120 mph (Category 3 hurricane)

(4): 121-130 mph (Category 3 hurricane)

(5): 131-139 mph (Category 4 hurricane)

(6): $140-155 \mathrm{mph}$ (Category 4 hurricane)

(7): 156-169 mph (Category 5 hurricane) 
Table A.3: Summary Statistics

\begin{tabular}{|c|c|c|c|c|c|}
\hline \multirow{2}{*}{\multicolumn{6}{|c|}{ Outcome variables }} \\
\hline & & & & & \\
\hline Giving to Habitat to help Katrina victims in [city] (\$ out of $\$ 100$ ) & 65.00 & 36.67 & 0 & 100 & 1343 \\
\hline Gave $\$ 100$ & 0.440 & 0.50 & 0 & 1 & 1343 \\
\hline Gave $\$ 50$ & 0.200 & 0.40 & 0 & 1 & 1343 \\
\hline Gave nothing & 0.090 & 0.29 & 0 & 1 & 1343 \\
\hline Gave other amount & 0.270 & 0.44 & 0 & 1 & 1343 \\
\hline \multicolumn{6}{|l|}{ Hypothetical giving to Habitat to help Katrina victims in [city] (topcoded } \\
\hline Subjective support for government spending to help Katrina victims in [city] & 4.854 & 1.44 & 1 & 7 & 1337 \\
\hline Subjective support for charity spending to help Katrina victims in [city] & 4.855 & 1.18 & 1 & 7 & 1333 \\
\hline \multicolumn{6}{|l|}{ Demographic control variables } \\
\hline Age & 47.94 & 16.3 & 18 & 93 & 1343 \\
\hline $\mathrm{Age}^{2} / 100$ & 25.63 & 16.2 & 3.2 & 86.5 & 1343 \\
\hline Non-Hispanic black & 0.120 & 0.33 & 0 & 1 & 1343 \\
\hline Non-Hispanic white & 0.735 & 0.44 & 0 & 1 & 1343 \\
\hline Other race/ethnicity & 0.145 & 0.35 & 0 & 1 & 1343 \\
\hline High school dropout & 0.128 & 0.33 & 0 & 1 & 1343 \\
\hline High school degree & 0.320 & 0.47 & 0 & 1 & 1343 \\
\hline Some college & 0.272 & 0.45 & 0 & 1 & 1343 \\
\hline College or more & 0.279 & 0.45 & 0 & 1 & 1343 \\
\hline Log household income & 10.57 & 0.92 & 7.8 & 12.8 & 1343 \\
\hline Dual income family & 0.530 & 0.50 & 0 & 1 & 1343 \\
\hline Married & 0.568 & 0.50 & 0 & 1 & 1343 \\
\hline Male & 0.463 & 0.50 & 0 & 1 & 1343 \\
\hline Single male & 0.200 & 0.40 & 0 & 1 & 1343 \\
\hline Lives in the South & 0.375 & 0.48 & 0 & 1 & 1343 \\
\hline Lives in the Northeast & 0.187 & 0.39 & 0 & 1 & 1343 \\
\hline Lives in the Midwest & 0.232 & 0.42 & 0 & 1 & 1343 \\
\hline Lives in the West & 0.207 & 0.41 & 0 & 1 & 1343 \\
\hline Working & 0.589 & 0.49 & 0 & 1 & 1343 \\
\hline Retired & 0.173 & 0.38 & 0 & 1 & 1343 \\
\hline Disabled & 0.078 & 0.27 & 0 & 1 & 1343 \\
\hline Unemployed & 0.040 & 0.20 & 0 & 1 & 1343 \\
\hline Not working for another reason & 0.120 & 0.32 & 0 & 1 & 1343 \\
\hline Any charity giving in 2005 & 0.808 & 0.39 & 0 & 1 & 1343 \\
\hline Any prior Katrina relief giving & 0.646 & 0.48 & 0 & 1 & 1343 \\
\hline Log giving to charity in 2005 (if Any charity giving in $2005=1$ ) & 5.845 & 1.61 & 0 & 12.2 & 1079 \\
\hline Log prior giving to Katrina relief (if Any prior Katrina relief giving $=1$ ) & 4.476 & 1.26 & 0 & 13.1 & 869 \\
\hline \multicolumn{6}{|l|}{ Survey Design Variables } \\
\hline Black pictures $\times$ Blurred & 0.302 & 0.46 & 0 & 1 & 1343 \\
\hline Blurred pictures & 0.603 & 0.49 & 0 & 1 & 1343 \\
\hline Black pictures & 0.503 & 0.50 & 0 & 1 & 1343 \\
\hline Slidell & 0.491 & 0.50 & 0 & 1 & 1343 \\
\hline Full-stakes version of the survey & 0.100 & 0.30 & 0 & 1 & 1343 \\
\hline Race-salient version of the survey & 0.095 & 0.29 & 0 & 1 & 1343 \\
\hline Audio manipulation: Republican & 0.494 & 0.50 & 0 & 1 & 1343 \\
\hline Audio manipulation: Economically advantaged & -0.008 & 0.70 & -1 & 1 & 1343 \\
\hline Audio manipulation: Received government assistance & 0.508 & 0.50 & 0 & 1 & 1343 \\
\hline
\end{tabular}


Summary Statistics (continued)

Audio manipulation: Prepares for hurricanes

Audio manipulation: Church attendance

Audio manipulation: Crime

Audio manipulation: Willing to help others

Audio manipulation: Sweat equity

Audio manipulation: Mention of looting

Perception variables

$\%$ of Habitat recipients in [city] that is black

$\%$ of Habitat recipients in [city] that is white

$\%$ of Habitat recipients in [city] that is from another race/ethnic group

$\%$ Recipients Black - \% Recipients White

$\%$ of voting Habitat recipients in [city] who voted for Bush in the 2004 election

Household income of Habitat recipients in [city] in \$'000 per year

$\%$ of Habitat recipients in [city] that received government cash assistance prior to Katrina

$\%$ of Habitat recipients in [city] that prepared as well as one can reasonably expect for Hurricane Katrina

$\%$ of Habitat recipients in [city] that attend religious services almost every week

$\%$ of Habitat recipients in [city] that have a criminal record

$\%$ of Habitat recipients in [city] that helped fellow hurricane victims

$\%$ of Habitat recipients in [city] that are willing to work hard in order to get ahead in life

Maximum sustained windspeed of Hurricane Katrina in [city] (1-8 scale)

Note: Sample has been weighted to adjust for oversampling of black respondents.

\begin{tabular}{rrrrr} 
Mean & S.D. & Min & Max & $\mathrm{N}$ \\
\hline 0.504 & 0.50 & 0 & 1 & 1343 \\
0.501 & 0.50 & 0 & 1 & 1343 \\
0.500 & 0.50 & 0 & 1 & 1343 \\
0.519 & 0.50 & 0 & 1 & 1343 \\
0.488 & 0.50 & 0 & 1 & 1343 \\
0.495 & 0.50 & 0 & 1 & 1343 \\
& & & & \\
50.4 & 19.6 & 0 & 100 & 1321 \\
36.2 & 19.5 & 0 & 100 & 1321 \\
13.4 & 11.6 & 0 & 100 & 1321 \\
14.1 & 37.3 & -100 & 100 & 1321 \\
& & & & \\
50.9 & 23.8 & 0 & 100 & 1325 \\
25.1 & 12.3 & 0 & 100 & 1328 \\
& & & & \\
33.4 & 27.9 & 0 & 100 & 1331 \\
& & & & \\
49.6 & 28.5 & 0 & 100 & 1329 \\
52.7 & 28.1 & 0 & 100 & 1329 \\
23.0 & 19.7 & 0 & 100 & 1323 \\
52.9 & 31.0 & 0 & 100 & 1320 \\
& & & & \\
42.8 & 22.9 & 0 & 100 & 1329 \\
4.8 & 1.7 & 1 & 8 & 1339 \\
\hline
\end{tabular}




\begin{tabular}{|c|c|c|c|c|c|c|}
\hline & \multicolumn{2}{|c|}{$\begin{array}{l}\text { Perceived \% HfH } \\
\text { recipients black }\end{array}$} & \multicolumn{2}{|c|}{$\begin{array}{l}\text { Perceived \% HfH } \\
\text { recipients white }\end{array}$} & \multicolumn{2}{|c|}{$\begin{array}{l}\text { Perceived \% black - } \\
\text { Perceived \% white }\end{array}$} \\
\hline & Coeff. & (S.E.) & Coeff. & (S.E.) & Coeff. & (S.E.) \\
\hline \multicolumn{7}{|l|}{ Panel A: Full Sample } \\
\hline Black pictures $x$ Blurred & $7.8^{* * *}$ & (2.1) & $-8.6^{* * *}$ & $(2.1)$ & $16.3^{* * *}$ & $(4.0)$ \\
\hline Blurred pictures & $-2.7^{*}$ & (1.6) & $3.3^{* *}$ & $(1.6)$ & $-5.9^{* *}$ & $(3.0)$ \\
\hline Black pictures & 1.6 & (1.6) & -2.5 & $(1.6)$ & 4.1 & $(3.1)$ \\
\hline \multicolumn{7}{|l|}{ Audio Manipulations } \\
\hline Republican & $-3.5^{\star \star *}$ & $(1.0)$ & $3.5^{\star * *}$ & $(1.0)$ & $-6.9^{* * *}$ & $(1.9)$ \\
\hline Economically advantaged & $-2.5^{\star *}$ & $(1.0)$ & $2.4^{* *}$ & $(1.0)$ & $-4.9^{* *}$ & $(2.0)$ \\
\hline Received government assistance & 1.4 & $(1.0)$ & -0.7 & $(1.0)$ & 2.1 & $(2.0)$ \\
\hline Prepares for hurricanes & 0.0 & (1.1) & 0.6 & $(1.0)$ & -0.6 & $(2.0)$ \\
\hline Church attendance & 1.7 & (1.0) & -1.0 & $(1.0)$ & 2.7 & $(1.9)$ \\
\hline Crime & 0.8 & (1.0) & $-2.3^{* \star}$ & $(1.0)$ & 3.1 & $(1.9)$ \\
\hline Willing to help others & 0.4 & $(1.0)$ & 0.5 & $(1.0)$ & -0.1 & $(2.0)$ \\
\hline Sweat equity & -0.7 & (1.0) & 1.4 & $(1.0)$ & -2.0 & $(2.0)$ \\
\hline Mention of looting & 1.6 & $(1.0)$ & $-1.8^{*}$ & $(1.0)$ & $3.3^{*}$ & $(1.9)$ \\
\hline Demographic Controls & \multicolumn{2}{|c|}{ Yes } & \multicolumn{2}{|c|}{ Yes } & \multicolumn{2}{|c|}{ Yes } \\
\hline $\mathrm{R}^{2}, \mathrm{~N}$ & 0.120 & 1321 & 0.150 & 1321 & 0.143 & 1321 \\
\hline \multicolumn{7}{|l|}{ Panel B: By respondent race } \\
\hline \multicolumn{7}{|l|}{ White respondents } \\
\hline Black pictures x Blurred & $5.9^{* *}$ & $(2.5)$ & $-6.2^{* * *}$ & $(2.4)$ & $12.1^{* * *}$ & $(4.6)$ \\
\hline $\mathrm{R}^{2}, \mathrm{~N}$ & 0.104 & 900 & 0.149 & 900 & 0.133 & 900 \\
\hline \multicolumn{7}{|l|}{ Black respondents } \\
\hline Black pictures x Blurred & $12.3^{* *}$ & $(5.9)$ & $-13.6^{* *}$ & $(6.2)$ & $25.9^{\star *}$ & $(11.8)$ \\
\hline $\mathrm{R}^{2}, \mathrm{~N}$ & 0.166 & 243 & 0.168 & 243 & 0.168 & 243 \\
\hline \multicolumn{7}{|l|}{ Panel C: By city } \\
\hline \multicolumn{7}{|l|}{ Biloxi pictures } \\
\hline Black pictures $\times$ Blurred & 2.8 & $(2.8)$ & $-6.0^{* *}$ & $(2.7)$ & $8.8^{*}$ & $(5.2)$ \\
\hline $\mathrm{R}^{2}, \mathrm{~N}$ & 0.103 & 672 & 0.128 & 672 & 0.119 & 672 \\
\hline \multicolumn{7}{|l|}{ Slidell pictures } \\
\hline Black pictures x Blurred & $12.9^{* * *}$ & $(3.1)$ & $-11.1^{* * *}$ & $(3.2)$ & $24.0^{* * *}$ & $(6.1)$ \\
\hline $\mathrm{R}^{2}, \mathrm{~N}$ & 0.166 & 649 & 0.194 & 649 & 0.188 & 649 \\
\hline \multicolumn{7}{|c|}{ Panel D: By Ethnic closeness (white respondents only) } \\
\hline \multicolumn{7}{|c|}{ Very close/close } \\
\hline Black pictures x Blurred & 1.3 & (3.6) & -1.4 & (3.6) & 2.7 & $(6.9)$ \\
\hline $\mathrm{R}^{2}, \mathrm{~N}$ & 0.163 & 422 & 0.187 & 422 & 0.182 & 422 \\
\hline \multicolumn{7}{|l|}{ Not very close/ not close at all } \\
\hline Black pictures x Blurred & $15.2^{* * *}$ & $(4.2)$ & $-17.0^{* * *}$ & $(4.0)$ & $32.2^{* * *}$ & $(7.8)$ \\
\hline $\mathrm{R}^{2}, \mathrm{~N}$ & 0.193 & 315 & 0.256 & 315 & 0.225 & 315 \\
\hline
\end{tabular}

Note: Robust standard errors in parentheses. Significance levels: ${ }^{*} 10$ percent; ${ }^{* *} 5$ percent; ${ }^{* * *} 1$ percent. Weighted to adjust for oversampling of African Americans. All regressions in all panels include the same controls as in Table 2. 


\begin{tabular}{|c|c|c|c|c|c|c|c|c|c|c|c|c|c|c|c|}
\hline \multirow[b]{3}{*}{ Dependent Variable } & \multicolumn{5}{|c|}{ Full sample } & \multicolumn{5}{|c|}{ White respondents } & \multicolumn{5}{|c|}{ Black respondents } \\
\hline & \multicolumn{2}{|c|}{$\begin{array}{c}\text { Black pictures } \\
\text { x Blurred }\end{array}$} & \multicolumn{2}{|c|}{$\begin{array}{c}\text { Corresponding } \\
\text { audio } \\
\text { manipulation }\end{array}$} & \multirow[b]{2}{*}{$\mathrm{R}^{2}$} & \multicolumn{2}{|c|}{$\begin{array}{c}\text { Black pictures } \\
\text { x Blurred }\end{array}$} & \multicolumn{2}{|c|}{$\begin{array}{c}\text { Corresponding } \\
\text { audio } \\
\text { manipulation }\end{array}$} & \multirow[b]{2}{*}{$\mathrm{R}^{2}$} & \multicolumn{2}{|c|}{$\begin{array}{c}\text { Black pictures } \\
\text { x Blurred }\end{array}$} & \multicolumn{2}{|c|}{$\begin{array}{c}\text { Corresponding } \\
\text { audio } \\
\text { manipulation }\end{array}$} & \multirow[b]{2}{*}{$\mathrm{R}^{2}$} \\
\hline & Coeff. & (S.E.) & Coeff. & (S.E.) & & Coeff. & (S.E.) & Coeff. & (S.E.) & & Coeff. & (S.E.) & Coeff. & (S.E.) & \\
\hline $\begin{array}{l}\% \text { Vote for Bush } \\
\quad(m=51 \mathrm{sd}=24)\end{array}$ & $-6.2^{\star *}$ & $(2.5)$ & $14.9^{* * *}$ & $(1.2)$ & 0.14 & -4.6 & $(2.9)$ & $13.5^{* * *}$ & $(1.4)$ & 0.16 & -2.2 & $(6.9)$ & $17.1^{* * *}$ & $(3.3)$ & 0.24 \\
\hline $\begin{array}{l}\text { Income of HfH recipients } \\
\qquad(\$ 000 / \mathrm{HH} / \mathrm{yr} \mathrm{m}=25 \mathrm{sd}=12)\end{array}$ & -1.2 & $(1.3)$ & $6.8^{* * *}$ & $(0.6)$ & 0.18 & -2.1 & $(1.6)$ & $6.7^{* * *}$ & $(0.7)$ & 0.19 & 5.1 & $(3.1)$ & $7.1^{* * *}$ & $(1.7)$ & 0.27 \\
\hline $\begin{array}{l}\% \text { Received gov't assistance } \\
\qquad(m=33 \mathrm{sd}=28)\end{array}$ & 1.2 & $(3.1)$ & $3.7^{* *}$ & $(1.5)$ & 0.07 & 0.8 & $(3.7)$ & $4.7^{* *}$ & $(1.8)$ & 0.08 & 0.5 & $(7.7)$ & 2.8 & $(3.7)$ & 0.18 \\
\hline $\begin{array}{l}\text { \% Prepared for hurricanes } \\
\qquad(m=50 \mathrm{sd}=29)\end{array}$ & 2.9 & $(3.1)$ & $9.0^{\star * *}$ & $(1.5)$ & 0.11 & 3.7 & $(3.7)$ & $11.4^{* * *}$ & $(1.8)$ & 0.12 & 6.1 & $(8.1)$ & $9.7^{* *}$ & $(4.1)$ & 0.20 \\
\hline $\begin{array}{l}\% \text { Attend church } \\
\qquad(m=53 \mathrm{sd}=28)\end{array}$ & -4.5 & $(2.8)$ & $27.2^{* * *}$ & $(1.4)$ & 0.28 & -3.9 & $(3.3)$ & $27.1^{* * *}$ & $(1.6)$ & 0.28 & -8.6 & $(6.6)$ & $25.1^{* * *}$ & $(3.4)$ & 0.35 \\
\hline $\begin{array}{l}\% \text { With a criminal record } \\
\qquad(\mathrm{m}=23 \mathrm{sd}=20)\end{array}$ & 1.0 & $(2.1)$ & $6.5^{\star * *}$ & $(1.0)$ & 0.15 & 1.4 & $(2.4)$ & $6.9^{* * *}$ & $(1.2)$ & 0.14 & 2.7 & $(5.2)$ & 2.2 & $(2.8)$ & 0.28 \\
\hline $\begin{array}{l}\% \text { Helping others } \\
\quad(m=53 \mathrm{sd}=31)\end{array}$ & 0.8 & $(3.1)$ & $27.5^{\star * *}$ & $(1.6)$ & 0.23 & 3.1 & $(3.7)$ & $27.2^{* * *}$ & $(1.8)$ & 0.24 & -7.8 & $(8.1)$ & $27.8^{\star * *}$ & $(4.1)$ & 0.30 \\
\hline $\begin{array}{l}\% \text { Willing to work hard } \\
\qquad(m=73 \mathrm{sd}=23)\end{array}$ & -1.2 & $(2.5)$ & 0.7 & $(1.2)$ & 0.10 & -1.8 & $(3.0)$ & 1.7 & $(1.5)$ & 0.10 & -1.2 & $(6.1)$ & -1.4 & (3.1) & 0.15 \\
\hline $\begin{array}{l}\text { Windspeed in town } \\
\quad(8 \text {-point scale } \mathrm{m}=4.8 \mathrm{sd}=1.7)\end{array}$ & 0.3 & $(0.2)$ & $\mathrm{N} / \mathrm{A}$ & $\mathrm{N} / \mathrm{A}$ & 0.07 & 0.1 & $(0.2)$ & $\mathrm{N} / \mathrm{A}$ & $\mathrm{N} / \mathrm{A}$ & 0.07 & 0.6 & $(0.5)$ & $\mathrm{N} / \mathrm{A}$ & $\mathrm{N} / \mathrm{A}$ & 0.17 \\
\hline
\end{tabular}

Note: Robust standard errors in parentheses. Significance levels: ${ }^{*} 10$ percent; ${ }^{* *} 5$ percent; ${ }^{* * *} 1$ percent. Full sample weighted to adjust for oversampling of African Americans. Means and standard

deviations reported under dependent variables refer to full sample. All regressions include the same control variables as in Table 2. The audio manipulations corresponding to the outcome variables are

listed in Appendix Table A.2. 